\title{
AREAS DE DESARROLLO INDÍGENA Y DISTRITOS MUNICIPALES INDÍGENAS. EL DESARROLLO INDÍGENA DESDE LAS POLÍTICAS DE CHILE Y BOLIVIA
}

Luisa Velasco. Magíster en Antropología y Desarrollo. Universidad de Chile

\section{INTRODUCCION}

Los Estados latinoamericanos han venido implementando desde comienzos de los años 90 distintos tipos de política en favor de las poblaciones indígenas a fin de diferenciarlas jurídicamente de la población llamada "nacional", por ejemplo, en algunos casos, introduciendo el uso de las lenguas originarias en los planes de educación formal, otros Estados se reconocen constitucionalmente multiétnicos y multiculturales y declarando respetar la alteridad de tipo étnico, como Nicaragua (1986), Brasil (1988), Colombia (1991), Bolivia (1994), o en su caso como Paraguay, México y Chile, reconociendo legalmente como destinatarios específicos de sus políticas de Estado.

Aunque para dirigentes indígenas, cientistas sociales, y la ciudadanía en general, el reconocimiento del sector indígena en las políticas estatales ya es un gran logro, se constata, al revisar el conjunto de derechos indígenas, estos no son viables en la práctica, y más bien su incorporación pretende tranquilizar a los mencionados sectores junto a la propia población indígena.

Algunas políticas hacia el sector indígena tienen un carácter de diferenciación del resto de la sociedad, lo que se ha denominado "discriminación positiva", que ha sido objeo de controversia. Por un lado, aquellos que la aprueban como es la población indígena, sector históricamente marginado, sus dirigentes, instituciones gubernamentales y no gubernamentales que apoyan este proceso y con el respaldo de sectores de la sociedad civil que están de acuerdo con este tipo de dotación de derechos. Por otro lado, aquellos sectores que se ven afectados (como por ejemplo terratenientes, políticos, y personas que tienen intereses en recursos naturales existentes en zonas indígenas) que las desaprueban y califican como de injustas.

En la actualidad, se pueden identificar tres tipos de derechos exigidos por los indígenas en sus demandas. Primero, se solicita al Estado salir de la marginalidad mediante la otorgación de derechos materiales (como la puesta en práctica de educación intercultural y bilingüe, solicitud de proyectos productivos, construcción de infraestructura, etc.). Segundo, se demandan derechos de tipo jurídico (como el ser reconocidos formalmente en las constituciones o que se reconozcan de manera formal los idiomas indígenas y formas de vida, etc.). Tercero, corresponden a los derechos a nivel simbólico, que se refiere más bien, a la actitud del Estado (a través de sus políticas y sus funcionarios) y al resto de la ciudadanía en torno al reconocimiento del mundo indígena como sujeto legitimado socialmente.

La demanda sobre la tierra - territorio, es transversal a estos tres tipos de derechos dentro del movimiento indígena. La tierra junto a otros recursos naturales, se han visto amenazados por varias razones (la sobrexplotación de dichos recursos, la erosión, las 
presiones de sectores empresariales como el forestal y el minero, entre otros), lo que representa una seria amenaza para su subsistencia como cultura.

En el contexto internacional, el reconocimiento de derechos indígenas tiene obviamente un respaldo de tipo institucional no gubernamental y se consolida muchas veces en los distintos Estados, a través de presiones internacionales para fomentar en los Gobiernos el reconocimiento de derechos de la población indígena, como el caso de la Cumbre para la Tierra 1992, la Declaración del decenio de los pueblos indígenas por NNUU en 1993, el Convenio 169 de la OIT (1989), entre otros.

Uno de los planteamientos que más se han enfatizado dentro de estos reconocimientos internacionales, es el del derecho que tienen los indígenas a acceder a un desarrollo y más específicamente a un desarrollo diferenciado del resto de la población, lo que se ha denominado "autodesarrollo", "etnodesarrollo", "desarrollo con identidad", "desarrollo con enfoque étnico", entre otros conceptos. Al introducirse esta idea de un desarrollo diferencial, se asume que el desarrollo será efectivo, que los indígenas por fin saldrán de la marginación, sin por ello haber sido aculturados, como era el resultado de otras políticas de asimilación impulsadas por el Estado.

El discurso acerca del papel de los pueblos indígenas en el desarrollo va cambiando. Si antes se señalaba a la población indígena como freno o barrera para el desarrollo nacional, ahora algunos sectores ambientalistas la identifica como contraparte en la gestión y conservación de recursos naturales. Antes se hablaba de la "problemática indígena" al afrontar la temática. Ahora apuntan a tratar de solucionar esta diferencia, se habla de un "desarrollo indígena" y de saldar una "deuda histórica" con estas poblaciones antes marginadas.

Este tipo de políticas discriminatorias respecto al resto de la población no indígena está además muy relacionada con el hecho de focalizar políticas para contrarestar la pobreza, ya que es sabido que los pueblos indígenas se caracterizan por estar dentro de los sectores que satisfacen de manera precaria sus necesidades básicas y acceso a servicios primarios (dentro de las variables que miden la línea de pobreza). Esta es una característica general de las poblaciones indígenas en Latinoamérica.

Tomando en cuenta entonces, que los Estados boliviano y chileno poseen políticas de desarrollo destinadas específicamente a la población indígena, nos interesa en la presente investigación analizar qué es lo que entiende en estos dos Estados como "desarrollo indígena" y cómo es llevado a la práctica mediante los instrumentos diseñados expresamente para tal fin como lo son las Areas de Desarrollo Indígena en el caso chileno y los Distritos Municipales Indígenas en el caso boliviano.

Nos parece necesario hacer una comparación de estos tipos de política y enfoque planteados por ambos Estados, que teniendo un mismo objetivo de desarrollo y respeto de las culturas indígenas, poseen características y marcos jurídicos distintos.

Pretendemos mediante este estudio varios objetivos relacionados entre sí. En primer lugar, acercarnos al fondo del planteamiento legal de desarrollo de parte de ambos Estados. Segundo, saber si mediante la implementación de estas leyes y sus instrumentos jurídicos, 
en base a la puesta en práctica del "desarrollo con identidad" o cómo se lo denomine, la cultura e identidad indígena se ve afectada negativamente o más bien se trata de una forma de fomentarla y reforzarla. Finalmente, nos interesa saber si las políticas sirven como facilitadores, o más bien como obstáculos en cuanto a la promoción del desarrollo indígena. 


\section{Capítulo 1)}

\section{INDÍGENAS Y ESTADO}

\section{i) Indígenas: cifras, ubicación e identidad}

Existen diferentes formas de identificar a la población indígena y cada país lo hace a su manera. Algunos han definido la etnicidad de su población (DERUYTTERE 1997) según el idioma hablado (Bolivia, México y Perú), otros según su ubicación geográfica (Venezuela, Colombia), y por último la variable a nuestro parecer más objetiva, la autodefinición (Colombia, Guatemala, Venezuela y Chile).

A modo de definir "quién es indígena", la ley indígena chilena señala que "indígenas" son “... los descendientes de las agrupaciones humanas que existen en el territorio nacional desde tiempos precolombinos, que conservan manifestaciones étnicas y culturales propias “ (Art. 1), y la propia ley establece los requisitos de acreditación de dicha categoría, tales como haber nacido en comunidades indígenas, ser hijo directo de un indígena (padre o madre). Bajo esta denominación, entran dos tipos de criterios de definición, primeramente de tipo consanguíneo “...los que sean hijos de padre o madre indígena..."(Art $2^{\circ}$ a) o "los descendientes de las etnias indígenas que habitan en el territorio nacional' ( $\operatorname{Art}^{\circ} 2 \mathrm{~b}$ ) y un segundo criterio relacionado a la autoadscripción de los indígenas "por asimilación cultural" o sea "los que mantengan rasgos culturales de alguna etnia indígena, entendiéndose por tales la práctica de formas de vida, costumbres o religión de estas etnias de un modo habitual o cuyo cónyuge sea indígena” .(Art $\left.{ }^{\circ} 2 \mathrm{c}\right) .^{2}$

Además de esta definición, en el Título VIII de la ley (Disposiciones Particulares) se señala específicamente y según su lugar de procedencia, los distintos pueblos originarios que se reconocen en el país. Por ejemplo el Art. 60 señala que "...son mapuches huiliches las comunidades indígenas ubicadas principalmente en la $X$ región $y$ los indígenas provenientes de ellas ${ }^{3}$...” Así mismo reconoce (Art. 62), por ejemplo, que “...son aymarás los indígenas pertenecientes a las comunidades andinas ubicadas principalmente en la I Región...". Los indígenas urbanos son de alguna manera discriminados a partir de estas definiciones, excluyentes, según veremos posteriormente.

En el caso de Bolivia, la autoidentificación, y el aspecto lingüístico son las principales variables utilizadas en la definición del "ser indígena", aunque en muchos casos también se considera el lugar de residencia ${ }^{4}$. Según Vadillo (97 pp31), el tratamiento que el Estado da en este sentido al tema indígena, en particular, la autodefinición, está dentro de "subjetivismo social".

\footnotetext{
${ }^{1}$ Ver Cuadro resumen de las poblaciones indígenas de Chile y Bolivia. Anexo \#1

${ }^{2}$ Este último criterio de definición por autoadscripción no es válido en el caso Rapa Nui.

${ }^{3}$ Según el censo de 1992 se sabe que la gran mayoría de personas que se reconocen como mapuches se encuentran habitando de forma permanente en la ciudad de Santiago.

${ }^{4}$ El Censo Indígena de tierras bajas realizado por SAE-PNUD en 1994 tomó en cuenta poblaciones rurales, pero no contó la población indígena que habita en centros urbanos.
} 
Existe la tendencia a que los habitantes de las "tierras bajas" 5 conformadas por las zonas Amazonía, Oriente y Chaco se los llame "indígenas", debido a que sus reivindicaciones ante el Estado comenzaron con esta denominación, mientras que en el caso de los habitantes de la zona altiplánica, especialmente de las etnias quechuas aymarás, que antes de la reforma agraria de 1952 eran conocidos como campesinos, se los denomine "originarios", por que consideran la palabra "indio" como despectiva. ${ }^{6}$

El Estado chileno reconoce formalmente la existencia en su territorio de 8 "principales étnias indígenas" ubicadas en diferentes regiones de norte a sur, como son, Aymará, Atacameñas, Quechuas, Collas, Rapa Nui o Pascuense, Mapuche, Kawashkar y Yagán, mientras que en territorio Boliviano se han identificado 36 grupo étnicos divididos a nivel general en las zonas geográficas del altiplano por un lado (4 etnias) y "tierras bajas" por otro (32 etnias). ${ }^{7}$

En Bolivia, los pueblos Pacahuara, Uru Hiruito y otros se consideran en condición vulnerable por la poca cantidad de miembros y la fragilidad de sus características culturales. En Chile, por su parte, los pueblos australes Kawashkar y Yagan, se encuentran en peligro de extinción cultural. En ambos casos, existen políticas que priorizan el rescate y preservación de estos pueblos.

Los grupo más representativos en el caso chileno son bs mapuches divididos en varias subgrupos según su zona de residencia, como lafkenche, pehuenche, huiliche.

En el año 1992 mediante el censo de población realizado a nivel nacional, se obtuvieron datos solamente de las tres etnias más representativas (Mapuche, Aymará y Rapa Nui) estableciéndose la Mapuche como mayoritaria con 928.060 (CPV92). Según la encuesta CASEN del año 1996 (que toma en cuenta a los 8 grupos reconocidos en la ley) la etnia minoritaria sería la Kawashkar con 138 personas. Según datos de 1992, los indígenas representan un $10.33 \%$ (o sea 998.385 indígenas)del total de la población chilena, valores significativamente menores en términos reales y nominales a Bolivia, asentándose gran cantidad de esta población en el área metropolitana. ${ }^{8}$

Mientras que en el caso boliviano los indígenas del altiplano, quechuas como aymarás, representan una gran mayoría, seguidos por los guaraníes y chiquitanos, habitantes originarios de las tierras bajas. En el último censo de población y vivienda, para identificar "lo étnico" se tomó en cuenta el idioma hablado. Por otro lado, el año 1994 el gobierno realizó con ayuda de PNUD un Censo especializado denominado "Censo indígena rural de

\footnotetext{
${ }^{5}$ Se denominan "tierras bajas" en relación a "tierras altiplánicas"a los departamentos de Santa Cruz, Pando, Beni y parte de Cochabamba y La Paz.

${ }^{6}$ De ahí que la institución gubernamental para asuntos indígenas antes llamada "Secretaría de Asuntos étnicos", pasó a llamarse Viceministerio de Pueblos indígenas y originarios. (VAIPO), actualmente Ministerio de Asuntos campesinos y Pueblos indígenas y Originarios

7 Ver en anexo Cuadros \#2 y \#3 Demografía de Pueblos indígenas en Chile y Bolivia según CENSO 92 y encuesta MECOVI 99 respectivamente y Cuadro \# 4 y Mapa \# 1 Población indígena en Bolivia por grupo étnico y ubicación

${ }^{8}$ Al conocer los resultados finales del Censo de 1992, la opinión pública quedó sorprendida. Los resultados de la gran cantidad indígena no esperada, fueron argumentados por algunos a la mala interpretación de la pregunta: "con qué étnia indígena se identifica usted"?
} 
tierras bajas" que posee solamente información acerca de indígenas habitando en esa zona, sin tomar en cuenta area urbana.

Los datos existentes en una reciente encuesta del Instituto Nacional de Estadística (Encuesta Mecovi 1999), habrían en Bolivia de 3.660.663 indígenas hablantes de lengua indígena ${ }^{9}$ es decir el 45,75 \% del total de la población boliviana (8.000.798). De estos, un reducido número, o sea 158.526, serían indígenas de tierras bajas, mientras que en las tierras altiplánicas, entre aymarás y quechuas serían una gran mayoría con un total de 3.512.837. Debido a que se toma la variable idiomática, creemos que una gran parte de la población indígena que ha perdido el idioma por desuso (especialmente en el caso de las tierras bajas y zonas urbanas) no aparecen reflejadas en este y otros censos.

La población indígena que habita en el área rural boliviana sigue siendo mayoritaria, contrariamente al caso chileno, aunque con el pasar del tiempo es evidente que va decreciendo. Del total de población urbana boliviana, el $15 \%$ (789.294) es indígena, mientras que del total de habitantes rurales el $63 \%$ (1.885.060)es indígena según su lengua hablada.

En Chile de los 998.385 indígenas de las tres principales etnias (datos del censo 1992), un 79.6\% habita en zonas urbanas y un $20.4 \%$ en zonas rurales. Sobre el total de la población indígena por grupo étnico, los mapuches poseen una población urbana del $79.2 \%$, mientras que los aymarás viven un total de $81.8 \%$ en área rural y los rapanui un $91.7 \%$.

A pesar de que en el caso boliviano, según el censo de 1992, el $42 \%$ de la población vive en zona rural, de los cuales el $70 \%$ es considerada "población dispersa" (poblaciones menores a 500 habitantes), se sabe que los grandes grupos étnicos como aymará, quechua, guaranie y chiquitano también tienden cada vez más a asentarse en centros urbanos como las ciudades de La Paz, Cochabamba, y Santa Cruz.

La cantidad de población urbana versus la rural, en ambos países (y como regla en otros de la región) tiende a crecer, debido al desgaste de las tierras y al poco acceso al agua en el campo, junto al aumento de la demanda de mano de obra en las urbes. En ambos casos, las cifras también demuestran que esta población se asienta en las comunas y en los barrios más pobres de las áreas urbanas.

Los principales desafíos que deben enfrentar familias indígenas migrantes son básicamente la falta de vivienda, o precariedad de estas y hacinamiento, discriminación laboral y/o falta de capacitación laboral $^{10}$, desempleo o entrada muchas veces al mercado informal con acceso irregular a dinero en efectivo.

Los aspectos materiales no son los únicos que se ven afectados en la calidad de vida de los migrantes, sino también los aspectos socio culturales como hábitos alimenticios, referentes culturales, espaciales, etc. y así adaptarse a patrones culturale s ajenos.

\footnotetext{
${ }^{9}$ En este censo la variable "idioma" se desglosa en dos subgrupos : -idioma hablado / idioma materno. Nosotros utilizamos los datos del primero.

${ }^{10}$ Informe de la Comisión Asesora en temas de desarrollo indígena, Santiago 2000
} 
En ambos países, es necesario tomar en cuenta la población indígena urbana con residencia permanente asentada en centros urbanos grandes y pequeños sean o no lugares indígenas históricos. Es importante en esta parte acotar que en Chile la Corporación Nacional de Desarrollo Indígena (en adelante CONADI) ha tomado en cuenta este aspecto del asentamiento urbano y ha creado la Oficina de Asuntos Indígenas en Santiago (OAIS), cuyo objetivo central, es el reforzamiento de la identidad indígena dentro de la población urbana, apoyando a este sector con proyectos educativos y productivos, principalmente. En el caso boliviano, el Gobierno actual introdujo la temática de los indígenas urbanos dentro de la problemática étnica formalmente por primera vez en el año 2000.

Como mencionamos en la introducción, la población indígena tanto urbana como rural se relaciona permanentemente con la pobreza como se especifica en estas cifras.

Según el Instituto Nacional de Estadística boliviano, en 1999 un 49 \% de los bolivianos pobres (tanto pobres moderados como pobres indigentes)son indígenas tanto en area rural como urbana, en relación a los $18 \%$ de indígenas que se consideran "no pobres". Siendo además el 33\% de los pobres urbanos indígenas, mientras que los indíge nas representan el 83.2 \% de los pobres rurales. Del total de 3.660.663 indígenas de toda Bolivia $27.5 \%$ son pobres moderados y son pobres indigentes el $53 \%$.

En Chile cambia notoriamente la situación de pobreza de los indígenas en relación con Bolivia, pero sigue arrojando cifras altas en relación al resto de la población. Según la encuesta CASEN (96), 25 \%de los indígenas viven en condición de pobreza no indigente, mientras que un $10.6 \%$ si lo es según la medición de la línea de pobreza, sin embargo, un $64.4 \%$ de los indígenas chilenos son considerados no pobres. En general, aunque los indígenas duplican la indigencia en relación a los no indígenas, se sabe según esta fuente, que los indígenas mapuche asentados en sus territorios de origen son los más pobres entre todos los indígenas.

$\mathrm{Su}$ actividad de productores-consumidores, trabajadores informales y otras características típicas de la subsistencia indígena hace que en las cifras no reflejen entradas económicas, posesión materiales, acceso a servicios primarios como luz eléctrica, agua potable, alcantarillado y otras denominadas "necesidades básicas".

Podría argumentarse que debido a la alta densidad de población indígena boliviana en relación a la chilena, su tendencia a la residencia fija en el área rural, juntamente con la poca repercusión de políticas estatales en estos lugares, los indígenas bolivianos mantienen rasgos culturales étnicos más marcados y prevalecientes en el tiempo que la población indígena chilena. Este segundo grupo por situaciones socio-económicas y restringido acceso a recursos naturales principalmente, se ha visto impulsado, a experimentar una migración al área urbana, siendo esta de tipo estacional, es decir, fijando como lugar final de residencia, los centros urbanos. Si bien los indígenas bolivianos son parte del mismo fenómeno, la diferencia es que poseen mayores lazos con su zona de expulsión, lo que permite una constante práctica de sus características socio-culturales.

Así como la migración es una causa de aculturación y pérdida de identidad indígena, la educación formal puede también serlo. En el caso chileno, a diferencia del boliviano, varias generaciones de indígenas han tenido acceso a programas de alfabetización, lo que 
ha significado, por un lado la pérdida paulatina de la lengua ancestral. Mientras que en Bolivia, la carencia de sistemas escolares, junto con la dispersión de la población indígena en el área rural, ha aportado para la preservación de rasgos culturales, que aunque cambiantes en el tiempo, poseen aún características peculiares.

Paradojalmente se ha notado que las políticas impulsadas desde los Estados, a través de esta "discriminación positiva" que venimos hablando, sus beneficios a los que se accede a condición de "ser indígena", y el contexto internacional de protección al medio ambiente y respeto a la alteridad, todo ello ha fomentado la revitalización de las identidades indígenas en ambos casos, tanto de los indígenas rurales como de los urbanos.

\section{ii)- Principales demandas y conflictos}

Aunque existan diferencias específicas dentro de las demandas de los indígenas chilenos y bolivianos, hay más bien similitudes en sus peticiones de derechos a sus respectivos Estados.

Las demandas indígenas presentes en Bolivia y en Chile, pueden ser grupadas como materiales, jurídicas y simbólicas de manera general. Las materiales se relacionan a la satisfacción de necesidades inmediatas y el acceso a recursos naturales, como tierra y agua, así como servicios, tanto salud como educación, vivienda e infraestructura. Un segundo grupo de demandas son las político-jurídicas que se relacionan con derechos humanos y jurídicos, en el reconocimiento formal de los Estados como países multiétnicos y plurilingües, acceso al poder, participación en decisiones y otros, los cuales están avalados internacionalmente por diversos instrumentos de Derecho Internacional. Finalmente las demandas de tipo simbólico van estrechamente ligadas al respeto de parte de la sociedad nacional hacia las culturas indígenas; la valoración de los idiomas nativos, la divulgación de la realidad indígena, la formulación de planes de estudio con contenido étnico, la no discriminación en el diario vivir a pobladores indígenas de parte de los no indígenas, etc.

Las demandas se parecen de manera global, como sucede por ejemplo en el tema educativo: las prioridades por una Educación Intercultural Bilingüe (EIB), con difusión de características socio-culturales (para ambos sectores de la sociedad indígena y no indígena), capacitación de profesores bilingües, creación de centros de enseñanza superior y liceos técnicos relacionados a áreas productivas, acceso libre a la educación etc.

En las demandas de salud podemos citar principalmente dos importantes demandas: infraestructura en áreas rurales y capacitación de personal indígena en áreas de salud e instalación de "médicos indígenas" y medicinas alternativas en los consultorios.

En el ámbito socio-económico por lo general, las demandas se relacionan a la necesidad de contar con infraestructura y financiamientos para llevar a cabo planes y programas productivos y organizativos. Más en el plano laboral, se solicitan la creación de planes de capacitación laboral.

Si como mencionamos, las demandas simbólicas y sociales de los pueblos indígenas en ambos países pueden asimilarse, hay una notoria diferencia entre las demandas jurídicopolíticas: los indígenas chilenos (sobre todos mapuches) solicitan ser tomados en cuenta 
como nación e incluso tener un territorio independiente con gobierno autónomo, mientras que los indígenas bolivianos, que en su mayoría están conformes con su situación y su relación con el Estado. ${ }^{11}$

Aunque con el pasar de los años las demandas pueden ir cambiando, el caso de la tenencia de la tierra (y luego el reconocimiento como territorio) representa una de las demandas principales no solo en Bolivia y Chile, sino de otros latinoamericanos.

En el caso boliviano, las tierras del Altiplano se encuentran sobreexplotadas y sobre parceladas por lo que se necesitan buscar nuevas maneras de uso más sustentables, por otro lado en la parte Amazónica y Oriente, la existencia de abundantes y ricos recursos naturales provocan constantes confrontaciones de terratenientes, transnacionales madereras y petroleras con los grupos indígenas de la región.

Esta es la misma situación que deben enfrentar comunidades mapuche de las Regiones del Bio Bio, La Araucanía y Los Lagos que pretenden recuperar tierras expropiadas. Estos conflictos o "tomas de tierras mapuche", a diferencia de otros por recursos naturales que ocurren por ejemplo en el norte grande en relación al recurso agua, se caracterizan por algún grado de violencia y desarrollo de acciones armadas.

En el caso chileno, específicamente del pueblo mapuche, se puede hablar de demandas de autonomía (Foerster 1999, Naguil 1997) y demandas de tipo "proyecto étnico" (Díaz Polanco 1989) donde existe, primeramente una oposición al mundo occidental. Desde la visión de mundo indígena, se rechaza la noción de Estado-Nación y se plantea una solución independiente que viene a ser una propuesta de un proyecto político.

Las instituciones indígenas bolivianas como la Confederación Indígena del Oriente Boliviano (CIDOB) o Central Unica de Trabajadores Campesinos de Bolivia (CSUTCB) y en el caso chileno Mali Witran Mapu, El Consejo de Todas las Tierras ${ }^{12}$ y otros grupos representativos (especialmente Mapuche, Aymará y Rapa Nui), se encargan de dar a conocer a la opinión pública y al Estado sus principales reivindicaciones y demandas. Muchas veces estas han sido conocidas públicamente a partir de hechos como tomas de terreno, marchas multitudinarias con determinados objetivos y otras han sido dadas a conocer en reuniones más formales con organismos estatales.

\section{iii) El indigenismo como política pública}

El indigenismo, principal forma de asumir la relación de los Estados latinoamericanos hacia su población indígena, se caracterizó por ser de tipo integracionista, además de

\footnotetext{
${ }^{11}$ Podrían ser la excepción demandas de indígenas e intelectuales aymarás con enfoque indianista de "volver al ayllu" o retomar aspectos culturales y simbólicos aymarás y sobre ponerlos a 1 sistema político occidental actual.

${ }^{12}$ Históricamente las organizaciones indígenas chilenas jugaron roles muy importantes en su papel de interlocutoras de los indígenas (principalmente mapuches) con el Estado. En las décadas de los años 30 y 40 agrupaciones como la "Sociedad Caupolicán" y "Corporación Araucana", en 1953 la "Asociación Nacional Indígena de Chile” (ANI), en 1961 la Federación Nacional Campesina e Indígena (FNCI), en 1965 el Movimiento Indígena de Chile (MICH), por citar algunos ejemplos. (Marimán 1997)
} 
proteccionista y paternalista (de parte sobre todo de parte de algunos sectores como grupos religiosos) desde mediados del este siglo hasta el presente.

Esta opción política destinada a los pueblos indígenas latinoamericanos fue declarada formalmente en el Primer Congreso Indigenista Interamericano (1949) y pretendió hacer justicia social y corregir de alguna manera las ideas etnocentristas de políticas anteriores. Este nuevo horizonte pretendía articular a indígenas, incluyendo sus características socioculturales a una sociedad moderna. Se pretendió compatibilizar esas características socioculturales con la idea de Nación practicando una suerte de "integración sin aculturación".

La práctica del indigenismo tiene dos etapas, la primera se caracterizada por el intento de homogeneización de parte del Estado a las poblaciones indígena, mientras que la siguiente y actualmente practicada, se relaciona más bien al intento de asistir zonas con predominante población indígena paralelamente al respeto de valores socio culturales de estos. Esto último dentro de una corriente internacional relacionada a la defensa y respeto del medio ambiente.

Si anteriormente los países latinoamericanos habían tenido un discurso explícito de destrucción de las culturas indias, el proyecto nacional pasa a dejar de lado la violencia simbólica de la asimilación y se torna más bien en una política a largo plazo, con cambios graduales, manteniendo el respeto por formas y características socio-culturales.

Si bien se suele culpar al Estado de la marginación en la que viven las poblaciones indígenas en general, y la falta de apoyo que reciben a modo de políticas sociales, notoriamente en los últimos tiempos las políticas públicas relativas a indígenas se han volcado con la estrategia denominada "discriminación positiva". A modo de saldar una deuda histórica en materia de asistencialismo, este sector de la población es priorizado en las políticas a manera de "lucha contra la pobreza".

Pareciera ser, sin embargo, que la marginación sigue siendo evidente aún cuando cada vez surjan más políticas especificas para elevar la calidad de vida indígena y se destinen montos extremadamente altos para este fin. En los hechos, las autoridades políticas no saben cómo llevarlas a cabo, o las políticas no cumplen sus objetivos o son puestas en práctica a medias.

ACLARAR Siguiendo con las contradicciones vemos que se habla de un Estado marginador por un lado y del mismo como homogeneizador. Creemos que la variable necesaria para el análisis y evaluación del tema es la cultural, desde el punto de vista que el Estado homogeneizador debería tratar de incorporar a la población indígena a sus políticas tomando en cuenta sus características socio culturales y hacer que la participación en su planificación de políticas sea efectiva y no sólo representativa del grupo beneficiario.

De otra manera, podría verse esta contradicción entre "desarrollo versus preservación de cultura" a partir del análisis por niveles autónomos de una sociedad. Siguiendo a Andueza (1997) “...las políticas desarrollistas no tienen que afectar sustancialmente otras esferas de la sociedad local, y aún más, tienen el mérito de garantizar la subsistencia que de otra manera estarían llamadas a la marginación." La ley podría distinguir distintos niveles en la sociedad donde repercute su implementación en miras de no causar desequilibrios socioculturales. 
Tanto Chile como Bolivia, desde sus inicios como Repúblicas independientes, han practicado diferentes tipos de indigenismo con mayores o menores grados de integración y homogeneización. Por su compromiso con la cultura indígena y respeto a sus características tradicionales, las políticas actuales tienden a salir de este enfoque, así como por su tratamiento discriminatorio de tipo positivo, pero en la práctica cierto tipo de paternalismo, nos hace concluir que quedan estructuras indigenistas en los niveles estatales encargados de formular políticas para dicha población.

\section{iv) Relaciones indígenas y Estado}

Si bien la historia colonial fue relativamente parecida en casi toda Latinoamérica, la relación de los gobernantes con los indígenas cambia relativamente al convertirse estos países en repúblicas independientes. Tanto Chile como Bolivia se constituyen en Repúblicas a comienzos del siglo XIX (1813 y 1825 respectivamente) y dada la alta densidad indígena en ambos países se elaboran políticas especificas destinadas a esta población.

\section{El caso chileno}

Ya a comienzos de la República chilena, en 1819 B. O’Higgins había mencionado en un bando la temática de la población indígena, donde declaraba la igualdad de derechos de éstos con el resto de los habitantes del país. En lo sucesivo, los indígenas deberían por lo que debían “... ser llamados ciudadanos chilenos y libres como los demás habitantes”. Sin embargo, la discriminación y abuso hacia esta población eran practicados de hecho más allá de la orientación del discurso de O'Higgins, que proyectaba deseo de protección al sector que había sido marginado socialmente y físicamente. (En: Andueza 1997:235)

La temática indígena dentro de la legislación chilena a lo largo del tiempo giraría en torno a una temática prioritaria como es la tenencia de la tierra. Esta problemática ha sido tratada en tres distintos ejes. El primer eje, se relaciona con la expropiación de tierras indígenas de parte del gobierno y la consecuente reubicación y redistribución de este recurso. En segundo lugar, la legislación indígena trata de proteger las tierras asignadas a indígenas (legalmente o no) frente a comerciantes y terratenientes inescrupulosos. Por último el tercer eje trata de una subdivición de la tierra y correspondiente tenencia individual de esta por parte de los indígenas (por ejemplo el Decreto de Ley 2568 de 1979). (IBID)

Un hito importante en el relacionamiento del Estado con los indígenas lo constituye el nombramiento del indígena B. Coñuepán en 1952 como Ministro de Tierras y Colonización, creándose en ese mismo año la División de Asuntos Indígenas (DAI) dependiente de esa entidad gubernamental.

Dando un gran salto en el tiempo, sin que hubieran habido en este transcurso leyes referidas directamente a la población indígena, en 1972 se promulgó la Ley 17.729, considerada la base de la ley indígena actual, y tomada como un primer intento de integrar diferentes aspectos como cultura, educación, tierra indígena, etc. Mediante esta Ley 17.729, se promueve por primera vez en la historia, la creación del Instituto de desarrollo indígena, 
cuyo objetivo era la promoción del desarrollo socio-cultural enfatizando en el tema educativo y de capacitación.

En 1979, como política del gobierno militar, se promulgó el Decreto Ley 2568 ("ley de divición de tierras"), que asume una política de desestructuración indígena que afectó una vez más al tipo de relaciones familiares y uso y acceso al recurso tierra. Esta política tenía el objetivo claro de insertar en zonas indígenas (especialmente mapuches) empresas forestales. Desde el punto de vista histórico, el período de la dictadura marca un retroceso que el movimiento indígena, que habría alcanzado logros en décadas anteriores "interrumpiendo un duro camino en que la exclusión habría paso a una situación de participación y entendimiento”. (Marimán 1997)

Con el retorno de la democracia, en 1989 la Concertación prioriza el tema indígena y en 1990 se crea la CEPI (Comisión Especial de Pueblos Indígenas) antecesora e la CONADI, donde se gesta el contenido de la ley indígena mediante acuerdos y trabajo con las bases. A pesar de que el gobierno chileno demuestra un claro interés por dar soluciones al tema indígena, el Convenio 169 de la OIT presentado al Parlamento chileno para ser discutido, nunca fue aprobado, encontrándose desde 1991 a nivel de Primer Informe en la Cámara de Diputados. El rechazo de parte de los partidos opositores al uso del término "pueblos" para referirse a los indígenas así como su oposición a los derechos que se les otorga en este tratado internacional ha significado que hasta el día de hoy el Convenio "sobre pueblos indígenas y tribales en países independientes" esté paralizado para su ratificación.

Al aprobarse la Ley Indígena (en adelante LI), la legislación chilena puede analizársela dentro del enfoque del pluralismo cultural desde el momento que se reconoce multiétnico y pluricultural. En el caso de este país, puede indicarse que el llamado "problema indígena", sus soluciones y políticas especificas son un reflejo de las relaciones del gobierno con el pueblo indígena mapuche, al ser éste el mayoritario poblacionalmente y el más demandante y contestatario en relación a los otros pueblos indígenas chilenos. Las poblaciones indígenas como Yagán y Kawashkar de los canales australes estuvieron muchas veces relegadas, por su poca población y por su ubicación, tanto a beneficios estatales como a relacionamiento con entidades estatales.

El gobierno de la Concertación en 1990 toma el tema indígena a un nivel de derechos humanos junto con el capítulo de reparación a las víctimas, presos políticos, verdad y justicia y medio ambiente, lo que demuestra el enfoque del tratamiento del tema de carácter "reparatorio". En su programa de gobierno (1989) promete adoptar medidas para el "reconocimiento y la preservación por parte del Estado de los pueblos indígenas como componentes de la sociedad chilena, valorizando su cultura y su carácter de pueblos integrantes de nuestra nacionalidad...”. (MIDEPLAN 2000)

El gobierno de Aylwin desde el inicio de su gestión planteó la necesidad de la aprobación de una legislación especifica de la temática indígena para lo que creó la Comisión Especial de Pueblos Indígenas o CEPI, que se encargó del proceso de análisis y formulación de la LI, aprobada en el Senado por unanimidad en 1993.

Luego se enfocó el tema indígena desde una perspectiva de "pobreza". Así lo muestra el discurso presidencial del 21 de mayo de 1994 “...hay otros chilenos, además de los niños y 
jóvenes, que también requieren de nuestra especial atención bajo el programa de superación de la pobreza...los pueblos indígenas, cuyas culturas tenemos el deber de preservar como testimonio de nuestras raíces comunes como nación, y que deben incorporarse al proceso de crecimiento y desarrollo económico." Las soluciones consecuentes para esta problemática, estuvieron también enfocadas desde el punto de vista de inversión en proyectos e infraestructura.

A lo largo de la presencia de la Concertación en el gobierno hasta nuestros días, las principales soluciones al tema indígena son planteadas a grandes rasgos en términos de otorgación de tierras en la región mapuche, derechos de agua en el norte a población aymará y atacameña y otorgación de becas indígenas en todo el territorio.

Entre los principales logros de las pólíticas indígenas de la Concertación, se pueden nombrar la aprobación en 1993 de la LI y todas las reformas de acceso a derechos y promoción de la identidad indígena que significa ésta; la creación de la CONADI, con su Consejo integrado por lideres indígenas. A nivel material se deben citar los logros que los indígenas en cuanto al acceso a recursos naturales, principalmente tierras y agua, proyectos productivos, capacitación, educación bilingüe e intercultural, becas indígenas y tratamiento del tema indígena en áreas urbanas, entre otros.

\section{La situación boliviana}

En el caso de Bolivia, las poblaciones indígenas altiplánicas fueron las que primero se relacionaron con el Estado en su calidad de "campesinos", luego, en las últimas décadas fueron incorporando a los pueblos indígenas de las llamadas tierras bajas.

Desde 1952, el Estado boliviano generalizó de alguna manera el acceso de la población rural a servicios educativos y de salud. Para algunos estudiosos, la Revolución de ese año, seguido por la Reforma Agraria de 1953 son el preludio al planteamiento actual de otorgación de derechos indígenas.

Por la situación geográfica y las dificultades de accesibilidad, así como por relaciones de tipo económico, el Estado boliviano se relacionó prioritariamente con la zona altiplánica, donde existían haciendas y sus pobladores eran tomados como mano de obra especialmente en actividades agropecuarias. Los pobladores de las llamadas "tierras bajas" fueron integrados a las políticas estatales mucho más tarde.

Las tierras habitadas por indígenas selváticos, de vida nómada, se colonizaron y explotaron desde fines del siglo XIX, es decir cuando comienza la relación del Estado con los indígenas altiplánicos, pero son tomados como mano de obra menos masivamente. Tanto el Estado como los terratenientes, comerciantes, etc, consideraban hasta hace poco tiempo el territorio indígena como sin dueño, libre o baldío al encontrarse despoblado y de hecho se implementaron planes de colonización y explotación de recursos naturales (caucho, madera) por privados mediante concesiones, sin respeto a sus poblaciones originarias.

Si bien durante todo el siglo XX existen políticas destinadas a la población llamada en ese entonces "de indios", en su mayoría tratados bajo en sistema feudal, la primera institución 
formal encargada del manejo estatal del tema indígena es el Instituto Indigenista Boliviano que fue creado en 1949 y que permaneció en el tiempo hasta 1994.

Desde 1952 después de la Reforma Agraria pasó a depender del Ministerio de Asuntos Campesinos y Agropecuarios que se mantuvo hasta 1993. Su actividad era promover algunos programas de rescate de valores culturales y comenzar un relacionamiento más estrecho con pobladores indígenas de tierras bajas tendiendo a conformar políticas integrales. El desarrollo indígena tomaba más en cuenta que nunca la idea de territorio indígena en todo el sentido de la palabra, en contraposición con lo que anteriormente se había considerado como tierras campesinas. Desde 1993 se crea la Subsecretaria de Asuntos indígenas (SAE), dependiente del Ministerio de Desarrollo Humano para volverse en 1997 Viceministerio de Asuntos Indígenas y Pueblos Originarios (VAIPO).

Desde 1980 a 1990 se van incluyendo en las Constituciones diferentes mecanismos dirigidos a terminar con las discriminaciones de tipo personal, étnica, de género, religiosa, etc. Después de muchos años se reconoce el plurilingüismo y el multiculturalismo de manera formal y se formulan políticas para proteger y fomentar estas características.

Durante el período gubernamental de 1989 a 1993, la cuestión indígena fue tratada dentro del Instituto Indigenista Boliviano dependiente del Ministerio de Asuntos Campesinos y Agropecuarios (MACA). Durante este período se dan grandes avances en materia jurídica y de derechos para las población es indígenas como la ratificación del Convenio 169 de la OIT (mediante Ley de la República 1.257), se reconocen territorios con recursos naturales a pueblos indígenas de la amazonía y se implementan programas de Educación Intercultlural Bilingüe.

Si bien era intención del Gobierno de Paz Zamora la implementación en 1990 de una Ley Indígena, traducida en una primera etapa en lo que llamaron "Plan Nacional para la defensa y el desarrollo indígena", no se logró concretar, y en el tema indígena se insertó transversalmente a varias leyes y decretos estatales. El proyecto de ley indígena estuvo a punto de presentarse al Parlamento Nacional era válida solamente para los pueblos indígenas de la Amazonía, chaco y oriente boliviano que iba a ser considerado luego como base de una Ley Indígena Nacional.

La temática indígena toma una especial atención en la agenda gubernamental a partir de una protesta indígena de la zona amazónica que terminó en una de las más grandes marchas Indígena llegadas desde sus comunidades a la ciudad de La Paz en 1990. Fruto de la marcha y las negociaciones se titularon territorios en la zona amazónica como el TIPNIS, TICH, TIM, reconociéndose por primera vez en la historia, grandes espacios territoriales a poblaciones indígenas, y a la vez declarándolos formalmente territorios "indígenas" mediante decretos supremos.

La organización representativa de los indígenas del altiplano, conocidos más bien como "campesinos", es la Central Unica de Trabajadores Campesinos de Bolivia (CSUTCB), que ha representado los intereses de este sector desde mediados del siglo, luego de la Reforma Agraria de 1953. Por su lado, los indígenas de las llamadas tierras bajas, 
conformaron su organización formalmente recién a partir de 1989 denominándola “Confederación Indígena del Oriente Boliviano”(CIDOB) ${ }^{13}$.

\section{v) Lo "indígena" en las legislaciones}

La actual constitución boliviana de 1994 reconoce en su artículo primero “ Bolivia, libre, soberana, multiétnica y pluricultural, fundada en la unión y la solidaridad de todos los boliviano." En la nueva Constitución se “... reconocen, respetan y protegen en el marco de la Ley, los derechos sociales, económicos y culturales de los pueblos indígenas que habitan en el territorio nacional, especialmente lo relativo a sus tierras comunitarias de origen, garantizando el uso y aprovechamiento sostenible de los recursos naturales, su identidad, valores, lengua, costumbres, e instituciones...”. (CPE Art. 171)

El reconocimiento jurídico declarado en la Constitución es una manera de aceptar la diversidad y el derecho a la alteridad y como principio ideológico es importante que el Estado se reconozca de esta manera, por la repercusión que puede tener en futuras decisiones y relaciones de ambos grupos.

La Ley de Participación Popular aprobada en 1994, en el marco de una política de descentralización, abrió las puertas a la participación ciudadana, la descentralización y su consecuente mejor repartición de recursos estatales. Mediante la necesidad de la adscripción a algunas categoría ciudadana (comunidad indígena, campesina o junta vecinal). La ley favorece la valoración de la identidad indígena en relación a la campesina ${ }^{14}$ y del otro lado, estimula a los miles de ciudadanos anteriormente desvinculados del Estado de manera legal, a participar de la ciudadanía boliviana mediante su pertenencia a una Organización Territorial de Base y sus derechos otorgados mediante la ley.

Una vez aplicada la ley, a fines del año 95 y durante 1996 y 1997 se fueron implementando paulatinamente las figuras de Distritos Municipales Indígenas en áreas indígenas en casi todos los municipios Bolivia, en base a solicitudes de las organizaciones indígenas o de instituciones de apoyo a estas.

El actual Gobierno boliviano (1997- 2002) reconoce que su atención hacia las poblaciones indígenas se incrementó debido a la organización y movilización indígena, a la vigencia de escenarios democráticos, a la emergencia temática en foros nacionales, a la declaración de NNUU del decenio internacional de los pueblos indígenas, a la revitalización de campesinos de su identidad de "originarios", a la formación progresiva de liderazgo político nativo y a la sensibilización sobre el tema hacia la clase política y demás ciudadanía.

\footnotetext{
${ }^{13}$ Esta gran institución que agrupa a los indígenas de las zonas del oriente, chaco y amazonía boliviana, se relaciona internacionalmente con otras similares como COICA (países de la cuenca amazónica), UNI de Brasil, COFENIAE de Ecuador, y AIDESEP del Perú, organizaciones indígenas que principalmente reivindican los derechos al territorio y sus recursos naturales por encontrarse en zonas tropicales donde los recursos naturales son abundantes (especialmente recursos maderables) y las poblaciones muy acosadas por su explotación permanente.

14 Principalmente en la zona llamada "tierras bajas”, osea indígenas de la zona amazónica, oriente y chaco.
} 
El gobierno de Banzer, como en un momento la Concertación chilena, propone el tema indígena desde una perspectiva económica al reconocer como desafios(VAIPO 1998) y metas, entre otros cubrir con servicios y principalmente poner atención al tema de la "lucha contra la pobreza y creación de oportunidades económicas", la comprensión y asumir la diferencia de lo indígena, cruzar la variable indígena a temas de medio ambiente, género y generacional, además de sensibilizar a la sociedad civil y política sobre la cuestión indígena "como factor crítico de gobernabilidad".

Sin embargo al estar esta política enfocada más hacia los territorios de las tierras bajas, el Estado ha enfrentado el año 2000 y 2001 a un revitalizado movimiento indígena-campesino del altiplano que solicita la modificación y/o nulidad de leyes anteriores y la aprobación de una nueva ley denominada "Ley Indio".

Con el cambio de gobierno(en 1997), puede decirse que se le dio poca continuidad a las acciones comenzadas con la Ley de Participación Popular especialmente del segundo al tercero se nota el cambio de la política indigenista. La del último y actual período se muestra más "culturalista" y "economicista" que de derechos colectivos, priorizando el contexto de lucha contra la pobreza.

Como objetivo estratégico del Plan Nacional para la población indígena denominado "desarrollo con identidad" se plantea "promover el desarrollo con identidad de la población indígena y originaria, para coadyubar al incremento de su calidad de vida, progreso económico, participación y afirmación cultural" (VAIPO 1998) lo que se llevaría a cabo en diferentes contextos como la lucha contra la pobreza, seguridad jurídica, desarrollo y fortalecimiento de marcos jurídico-institucionales. Estos desafios se enmarcan dentro de una política indigenista con participación delimitada por las acciones del gobierno. La ratificación del Convenio 169 por parte del Estado boliviano en 1990, hace que derechos inscritos en este se vean reflejado en algunas leyes, aunque no siempre llevados a la práctica.

Leyes como la Ley Forestal (Art. 32), el Nuevo Código Minero, la Ley del Medio Ambiente, la Ley de Hidrocarburos (Art. 7), la Ley del Instituto Nacional de Reforma Agraria (INRA) se refieren a los derechos de los pueblos indígenas sobre sus Tierras Comunitarias de Origen (TCOs), en relación al Estado o empresas privadas que atenten contra sus recursos de tierra y otros recursos naturales, afectando directamente a intereses comunitarios indígenas.

La historia de la legislación boliviana relacionada a los pueblos indígenas en Bolivia esta marcada por una diferencia enorme entre las relaciones del gobierno con la población indígena de las tierras bajas y por otro lado con indígenas del altiplano. Si bien la reforma agraria de 1952 trató de reivindicar los territorios indígenas que se encontraban en manos de hacendados, indiscutiblemente desde la década de los 90 se prioriza la temática indígena de tierras bajas a modo de recuperar tiempo perdido durante su marginamiento, pero además a manera de crear cierta protección jurídica a territorios y recursos naturales que se hallan en peligro de ser sobre explotados.

En cuanto al caso chileno, entre los años treinta a sesenta del siglo XX, las políticas chilenas en cuanto al tema indígena giraron prioritariamente en torno a la temática de la 
tenencia de tierra, con marcadas tendencias a ser políticas asimilacionistas e integracionistas, al igual que en otros países latinoamericanos. El tema indígena se lo trató más bien dentro de un enfoque campesinista.

Dando un gran salto en la historia de las políticas indigenistas chilenas, hablaremos desde las políticas a partir del retorno de la Democracia en 1989, como un primer período donde se sientan las bases jurídicas de derechos a Población indígena -que en este estudio analizamos- y en un segundo período, con el Gobierno de Frei, donde se ponen en práctica algunas propuestas políticas del Gobierno anterior.

En octubre de 1989 en Nueva Imperial, IX región, fue acordada una propuesta de política indígena por integrantes de la Concertación y dirigentes indígenas huilliches, mapuches, aymará y rapa nui. Básicamente se comprometieron al reconocimiento institucional de Pueblos Indígenas, la creación de la Comisión Especial de Pueblos Indígenas (CEPI) para luego ejecutar el plan político para el sector indígena desde la CONADI, a fin de impulsar iniciativas legislativas, administrativas y económicas necesarias para la concretización de planes y medidas de programas para los Pueblos Indígenas de Chile.

La Ley Indígena, (que tardó tres años en ser discutida y aprobada) fue el fruto de largas conversaciones entre integrantes del gobierno democrático y dirigentes indígenas. Con su aprobación un nuevo mundo de derechos ciudadanos y específicos se dotan a la población indígena.

Aspectos como la discriminación no se encuentran directa o formalmente referidas en la Constitución boliviana, contrariamente a la LI chilena, que indica en su Art. 8 que "se considerará falta la discriminación manifiesta e intencionada en contra de los indígenas, en razón de su origen y su cultura."

El derecho consuetudinario tratado de forma extensa en la Nueva Ley de Procedimiento Penal boliviana de 1999, se menciona en su Art. 54 "La costumbre hecha valer en juicio entre indígenas pertenecientes a una misma etnia, constituirá derecho, siempre que no sea incompatible con la Constitución Política de la República."

\section{vi) El desarrollo indígena desde el Estado}

Si bien según la teoría de Bonfil sobre el etnodesarrollo, y otras teorías denominadas de autodesarrollo, "desarrollo culturalmente sustentable", paradojalmente los Estados han sido escritas a modo de cuestionar al Estado su acción aculturizadora con los pueblos indígenas, los estados utilizan en los últimos años estos conceptos para referirse a un desarrollo diferencial de la población en general y argumentar una metodología diferente de intervención en áreas con población indígena.

A modo de ejemplo, por "etnodesarrollo" Bonfil Batalla entiende "...el ejercicio de la capacidad social de un pueblo para construir su futuro, aprovechando para ello las enseñanzas de su experiencia histórica y los recursos reales y potenciales de su cultura, de acuerdo con un proyecto que se defina según sus propios valores y aspiraciones...". Dentro del mencionado etnodesarrollo, elementos de la teoría del control cultural, que serviría como metodología del etnodesarrollo, son planteados por Bonfil B.(1995) como "la 
capacidad social sobre los recursos culturales, es decir sobre todos aquellos componentes de una cultura que deben ponerse en juego para identificar las necesidades, los problemas y las aspiraciones de la propia sociedad e intentar satisfacerlas, resolverlos y cumplirlas".

Así mismo, el planteamiento de un desarrollo denominado "culturalmente sustentable", puede ser relacionado con el desarrollo económico y que practicados en conjunto implica " no solamente la no destrucción como sistema y como grupo humano de un pueblo, sino también la mantención de una identidad como tal."(Durston 1995)

Es importante según éstas y otras posiciones de etnodesarrollo tanto la recuperación de elementos culturales grupales y enajenados como tierra, historia, tecnología, como el fortalecimiento de las organizaciones sociales comunales. Al crear fortalecer y ampliar las condiciones de autonomía, se abren las posibilidades de un autodesarrollo y etnodesarrollo.

Cada Estado y sus respectivos gobiernos definen líneas de acción para sus políticas sociales. Para un acercamiento del enfoque Estatal hacia el desarrollo indígena tomaremos en cuenta documentos formales de las instituciones gubernamentales encargadas de este tema. No pretendemos hacer un análisis de discurso de los textos institucionales, pero nos basamos en éstos para deducir qué es lo que entiende el Estado boliviano y el chileno como desarrollo indígena.

Sabemos que estos conceptos y usos de términos no responden directamente muchas veces a políticas nacionales, sino más bien a autores de los textos, sin embargo, creemos que al poner los conceptos en circulación, pueden influenciar en las perspectivas y tal vez luego en formulación de políticas.

Si bien se sigue una línea internacional en cuanto al tratamiento de los derechos de los pueblos indígenas y del concepto de desarrollo en torno a estos, se ha notado diferentes enfoques según los gobiernos de turno en que son planteados. De manera resumida, y remontándonos preferentemente a los últimos tres gobiernos en ambos casos (Bolivia y Chile) analizaremos acerca del término "desarrollo indígena" y otros relacionados a este concepto.

Es en el primer Gobierno de la Concertación (1989) que los derechos de los Pueblos indígenas se hacen palpables y van con el pasar del tiempo tomando forma, tanto en leyes como en percepción gubernamental. El presidente Aylwin se comprometió a reconocer en plenitud los derechos políticos, sociales, económicos y culturales de los pueblos indígenas, estos vistos como componentes de la sociedad chilena.

En 1993 fue aprobada y posteriormente presentada la ley indígena, principal y gran aporte del gobierno de Aylwin a la temática indígena, con estas palabras “...el país conoce la voluntad de mi gobierno de considerarlos constructivamente, sobre la base del reconocimiento de su situación particular, de la interlocución franca con sus organizaciones más representativas y del claro espíritu de buscar soluciones que concilien sus particulares intereses con el bien común nacional...". (MIDEPLAN 00b)

Si bien en un principio el gobierno de Aylwin se dedicó a la implementación de programas de tipo infraestructura, becas indígenas, proyectos de desarrollo autogestionados y atención 
jurídica sin costo a los indígenas, el año 1994 se enfocan un poco más hacia un proceso de crecimiento económico, como habíamos visto antes. El tema indígena se enfoca en esta etapa dentro de la superación de la pobreza.

El segundo gobierno de la Concertación, el poder desde 1994, comienza su política para sector indígena mediante la dotación de nuevas tierras, basándose en los objetivos prioritarios de la ley. En 1996 la Encuesta Cassen tomó por primera vez la variable indígena, obteniéndose datos importantes acerca de la situación de la población indígena. Durante el año 97 se formalizó la creación de las Areas de Desarrollo Indígena junto con impulsar una propuesta de Plan Trienal de desarrollo indígena, pretendiendo hacer cambios dentro de la CONADI y darle un enfoque más nacional a la temática indígena.

El año 98 el enfoque gubernamental basado en dos principales ejes, pretende acercarse a la problemática en cuestión. El primero fue el respeto y reconocimiento a la cultura, las tradiciones, derechos como personas y ciudadanos de los indígenas chilenos, siendo el segundo eje político el tratamiento del tema de la superación de la pobreza mediante la dotación de oportunidades para hacerlo. El mismo año, en medio de conflictos violentos por demandas de tierra en el sur del país, el gobierno declaró "día de los pueblos indígenas" el 23 de Junio.

Durante el gobierno de Frei, es importante recalcar el conflicto por la construcción de la Hidroeléctrica Ralco, que trajo al Gobierno problemas al interior de la CONADI y enfrentó la posición gubernamental con el movimiento indígena y parte de la sociedad civil.

Pasando al último período gubernamental, en su discurso del 21 de mayo del 2001, Lagos reconoce un esfuerzo de su gobierno por impulsar el desarrollo de los pueblos indígenas principalmente mediante capacitación para la gestión, y asistencia técnica, pero no habla de un desarrollo con identidad, aunque documentos del MIDEPLAN y de la CONADI si lo hacen.

Es en este último período se le da a la temática del "desarrollo indígena" una mayor atención para ser tomado como política nacional. Se habla de conceptos como "calidad de vida indígena" entendida como "los propios indígenas los que determinen el tipo de necesidades y las condiciones adecuadas a sus propias perspectivas etnoculturales..." y de "autodesarrollo" indígena sustentable(MIDEPLAN 2000b). "...este desarrollo con identidad que se fundamenta en hecho de que cada sujeto es autónomamente responsable de su propio desarrollo, debe entenderse sobre la base del mutuo respeto, el diálogo y el intercambio armónico e intercultural con las comunidades, grupos o instituciones no indígenas del área y de la región..." (CONADI s/f b pp23)

Se busca un desarrollo con identidad "sobre la base tanto de la participación indígena, como del respeto a sus derechos humanos, político, social y a sus derechos como pueblos indigenas.”.

En los últimos tres períodos presidenciales en Bolivia la política indígena ha seguido un mismo rumbo, con una política indigenista comenzada a fines de los años 80 , aunque con matices diferentes según el Gobierno de turno y los intereses que estos poseen. 
A principios de los años 90 Paz Zamora (1989 -1993) comienza a introducir en la esferas políticas la temática indígena, (especialmente de tierras bajas) como de urgente solución y priorización. Un proyecto de ley fue presentado en el Senado. Aunque nunca fue aprobado como tal, sin embargo se refería muy claramente a lo que tomaría como desarrollo indígena dentro de un Plan denominado "Para la defensa y el desarrollo indígena". Este plan sugería el tratamiento del tema indígena en cuatro ejes para cumplir con los objetivos de desarrollo indígena. El reconocimiento y dotación de espacios territoriales a la población indígena, el reconocimiento de las identidades étnicas y socioculturales, la inserción de los indígenas dentro de los procesos de desarrollo nacional y la dotación de una legislación indígena que dada dentro del marco de una concertación.

El Estado Boliviano consideraba importante trabajar “...en la búsqueda de una nueva normativa en favor de los grupos étnicos de Bolivia, consideramos que el nuevo espacio político que tiende a consolidarse a breve plazo, debe tender hacia los modelos de manejo indígena de los recursos del bosque como los modelos más adecuados para la preservación de los recursos naturales...".(Ministro Bertero en Libermann 1991)

Durante el período de Sanchez de Lozada (1993-1997) el principal impulso al desarrollo indígena lo dio la Ley de Participación Popular y la Ley INRA, donde se especifica jurídicamente se dotan de tres instrumentos de participación y desarrollo. Por un lado los Comités de vigilancia, las Organizaciones Territoriales de Base (OTBs) y los Distritos Municipales Indígenas (DMIs).

En el Manual de Planificación Participativa en áreas indígena s editado en este periodo presidencial toma por "políticas étnicas de apoyo al desarrollo indígena" "el reconocimiento de los diversos pueblos indígenas del país, su plena participación ciudadana y el mejoramiento de su situación económica y de acceso a servicios, así mismo, la recuperación de sus capacidades culturales como factor de desarrollo." Por lo que "la política étnica se ha propuesto favorecer el mejoramiento de la actual situación de los pueblos indígenas a través de su reconocimiento y participación, de una mejor atención de sus necesidades, y de la promoción de su desarrollo económico por parte del Estado y del fortalecimiento de las capacidades de cada pueblo para la participación ciudadana y la gestión del propio desarrollo". (MDSP 1997)

Durante el gobierno de Banzer, "Desarrollo con identidad" es el nombre de la política gubernamental emitida por el Ministerio de Desarrollo sostenible y planificación teniendo en cuenta que el Estado reconoce como indígena y originaria a aproximadamente la mitad de la población total del país (4.2 millones de personas) invirtiendo en acciones relacionadas con la etnicidad e identidad indígena del país y tomando en cuenta por primera vez a la población indígena urbana.

El objetivo del Plan Nacional es "combatir las condiciones de pobreza extrema y mejorar la calidad de vida de las comunidades indígenas y originarias...generando el fortalecimiento organizacional, técnico y empresarial de sus organizaciones comunitarias así como la inversión en proyectos comunitarios de desarrollo con identidad y de conservación de la biodiversidad." (Semo 1999) 
En conclusión, los gobiernos bolivianos toman como desarrollo indígena un "desarrollo con identidad", reflejado principalmente en la participación indígena en tomas de decisiones (habiendo previamente fortalecido sus organizaciones) y en el manejo sostenible de sus recursos existentes en territorios de tenencia indígena.

Como "enfoque étnico"15 el Estado parece en la práctica entender dos cosas. Primeramente la participación indígena, asegurada por le hecho de responder a las encuestas - "los que responden participan" (líneas base, diagnósticos de inversión en el caso de las ADIs y cuestionarios de la metodología de Planificación Participativa) y, por otra, por integrar mesas de diálogo (el caso de representantes indígenas de algunas ADIs con instituciones estatales) o participación de reuniones municipales (caso de subalcaldes indígenas de los DMIs).

Por otro lado, el hecho de hacer referencia, dentro de los planes de desarrollo a aspectos y variables culturales como son "autoridades tradicionales" o respeto a los "usos y costumbres" (ley boliviana) o "territorio ancestral"(ley chilena), pareciera que para los Estados se trata en sí de un enfoque diferencial.

Las metodologías participativas (que analizamos en el tercer capítulo) que determinen la visión de un desarrollo con características socio-culturales, que arrojen como resultado programas de desarrollo desde la perspectiva indígena, deben ser elaboradas cuidadosamente con una visión de largo plazo.

Quedan dos alternativas como análisis del enfoque de los gobiernos. La primera es que por carencias metodológicas no han podido llegar a los objetivos deseados, y la segunda, que utilizan como excusa para desligarse de las demandas indígenas que solicitan trato especial a este tipo de política (o nombre de política, más que el tipo).

\footnotetext{
${ }^{15}$ Es importante aclarar que los Gobiernos se inclinan más a gestar sus políticas indígenas dentro de este enfoque y no por ejemplo en el enfoque desde la perspectiva de administración territorial, que podría haber sido el caso de las ADIs y los DMIs
} 


\section{Capítulo 2)}

\section{POLÍTICAS PARA POBLACIÓN INDÍGENA EN LOS 90: Ley Indígena chilena y Ley de Participación Popular boliviana}

El tema del desarrollo de los pueblos indígenas desde una perspectiva del Estado y la puesta en práctica de ésta es el fondo de este estudio comparado. Al poseer población indígena Chile como Bolivia han venido implementando una serie de políticas destinadas a este sector de la población, con el objetivo de mejorar su calidad de vida. Las leyes que comparamos seguidamente, son el sustento del planteamiento de desarrollo desde los Estados que estudiamos.

No es fácil comparar la esencia y el carácter de las leyes que a continuación intento analizar de manera general, especificando en dos figuras legales que contienen como son los Distritos Municipales Indígenas y las Areas de Desarrollo Indígena. Se hace difícil esta labor, ya que si bien ambas leyes han sido aprobadas casi paralelamente en el tiempo (Ley Indígena chilena 1993 y Ley de Participación Popular 1995), están basadas en historias y demandas diferentes, además que poseen otras características, como objetivos e instrumentos que las diferencian. ${ }^{16}$

Mientras que la Ley Indígena chilena (Ley $\mathrm{N}^{\circ}$ 19.253, en adelante LI), como su nombre lo indica, ha sido elaborada pensando en un sector específico de la población de ese país, la Ley de Participación Popular (Ley \# 1551 en adelante LPP), involucra al total de la población boliviana y no solamente al sector indígena.

Por otro lado, se sabe que la LI ha surgido de la demanda del sector interesado, quienes durante varios años, especialmente con el retorno de la democracia en 1989, han solicitado al Estado la necesidad de conglomerar sus derechos a través de una ley, mientras que la ley boliviana formó parte de varios cambios constitucionales, que en su momento un sector de la población boliviana denominó "leyes malditas", junto con la Ley de Reforma Educativa y Ley de Capitalización.

Así mismo, en el sentido de alcance, mientras que la LPP está pensada para el beneficio del total de la población boliviana y orientada específicamente a nivelar de alguna manera zonas marginadas y rurales con zonas -generalmente urbanas- que anteriormente monopolizaron los recursos estatales, la LI chilena está pensada específicamente para la atención exclusiva de la población indígena, que representa aproximadamente el $10 \%$ del total de la población nacional.

La LI chilena fue consolidada formalmente en 1993 luego de 4 años de negociaciones de líderes indígenas con el gobierno central y agrupa todo lo relacionado a los derechos indígenas en cuestión de territorio, servicios básicos, educación bilingüe, derechos culturales y de identidad y sobre recursos naturales, además de otros. Mientras tanto, en el caso de Bolivia, los aspectos jurídicos y derechos y obligaciones relacionados a la población indígena se manifiestan en acápites específicos en cada una (en la mayoría) de

\footnotetext{
${ }^{16}$ Ver en anexo Cuadro \# 5 Resumen comparativo de las Leyes (LI y LPP)
} 
las distintas leyes, específicamente en las nuevas, generadas desde 1994 y los cambios hechos a la Constitución Política del Estado el mismo año.

Si bien, ambas leyes pretenden saldar daños históricos con poblaciones marginadas anteriormente y están enfocadas hacia un desarrollo humano, la descentralización administrativa y de recursos es la característica de la LPP, mientras que la LI intenta más bien focalizar recursos para atender a la población indígena.

La boliviana, por su lado tiene como objetivo sentar presencia del Estado, y con ello recursos antes no destinados a las zonas rurales y alejadas, y la chilena, como su nombre lo indica, enfoca sus prioridades a la población indígena, también marginada del resto de la población nacional.

La LPP apunta a una "construcción de ciudadanía" dada en el acceso a derechos a todos por igual, emparejando los derechos de las poblaciones donde se busca la participación de una sociedad civil ${ }^{17}$ anteriormente olvidada. En el caso chileno se trataría más bien de una "construcción de una ciudadanía diferenciada", un trato preferencial a la sociedad civil "más débil", practicando lo que se denomina "discriminación positiva", donde la sociedad civil debe diferenciarse y otorgárseles ciertos derechos para de alguna manera alcanzar los logros en sentido de desarrollo humano y social al que supuestamente alcanzó el resto de la sociedad.

\section{i) Los comienzos de estas legislaciones}

En octubre de 1989 en Nueva Imperial, IX Región, fue entregada una propuesta de política indígena por integrantes de la Concertación a dirigentes indígenas mapuches, aymará y rapa nui comprometiéndose al reconocimiento institucional de pueblos indígenas, y la creación de una Corporación Nacional de Desarrollo Indígena, para impulsar iniciativas legislativas, administrativas y económicas necesarias para la concretización de planes y medidas de programas para los Pueblos Indígenas de Chile.

La Ley 19.253 denominada "Protección, Fomento y desarrollo de los pueblos indígenas", (D. Oficial del 5 de octubre de 1993) tomó aproximadamente tres años en ser discutida y aprobada. Parte de la discusión se basó en el contenido y de manera profunda en los términos que debía contener esta, existiendo conflicto principalmente en el uso de conceptos como "pueblo" y "territorio".

La LI significaría, por un lado, un "ejercicio democrático", por el hecho de instaurar la elección de 8 delegados indígenas al consejo de la CONADI y por el otro se constituiría en una especie de mediadora al seno del movimiento mapuche. (Foerster 1999:54)

En Bolivia la LPP fue gestada en el marco de una reestructuración de la Constitución y de otras dos leyes que fueron ampliamente debatidas y cuestionadas en diversos sectores de la población como son la reforma educativa y la de descentralización.

17 La "sociedad civil”, es entendida por la LPP como comunidades indígenas, campesinas, y urbanas 
Ambas leyes que tocan temas nunca antes reglamentados y que provocarían cambios sociales de gran impacto en la sociedad indígena, despertaron en los sectores interesados incredulidad y desconfianza hacia el Estado. A pesar de haber ocurrido esto, una vez puestas en práctica las leyes que eran vistas "al servicio del Estado", sus detractores aceptan utilizar sus beneficios para fines personales.

Volviendo a Bolivia, un gran sector de las organizaciones indígenas de tierras bajas, tomaron la idea de la participación popular como una vía de hacer conocer sus demandas. La ley fue interpretada como una continuidad de las políticas que el gobierno de Paz Zamora había comenzado el 93 y que habían sido especialmente benevolentes con el sector indígena, especialmente en la otorgación de derechos y del acceso a recursos.

Una vez aprobada la LPP, en las elecciones municipales de 1995, se permitió a millones de personas locales que antes de este tipo de descentralización no tenía oportunidad para hacerlo, participar en las votaciones municipales. Así mismo la ley viabilizó la participación indígena en las esferas políticas y ejercer el derecho de postular dirigentes indígenas a cargos municipales, sin embargo al no permitirse las candidaturas independientes, estos tuvieron que incursionar en campos político-partidistas, lo que a veces disminuyó el compromiso étnico. Una de las barreras para la masificación de las votaciones en sectores rurales fue la falta de documentos de identificación en la población indígena restó fuerza a las candidaturas de los políticos indígenas. Como resultado de esta primera experiencia, se tuvieron 464 alcaldes entre campesinos e indígenas, tanto en zonas rurales como urbanas.

\section{ii) “Indígenas" versus "Pueblos Indígenas"}

Al momento de definir el concepto de indio o indígena, se enfrentan dificultades en esferas tanto políticas, como de investigadores e instituciones estatales. Cada país, ha definido a su población indígena con diferentes términos según sus intenciones y planteamientos políticos e interpretaciones. Se han hablado de "nativos", "autóctonos", "poblaciones aborígenes", "minorías nacionales", " minorías étnicas", "indios", y otros, incluso hay países que diferencian su definición entre sus habitantes indígenas ${ }^{18}$.

En reuniones de las comisiones de NNUU se dio una discusión acerca del uso del término "pueblo indígena" en relación al término "indígena" a secas. El tema en discusión sobre el uso del término "pueblo" se vincula bajo los instrumentos de NNUU con el derecho a la autodeterminación. Así “...el uso del término "pueblos" se refiere a una colectividad donde los derechos son gozados por grupos así como por individuos. Los países que protestan, no reconocen ni el derecho a la autodeterminación ni el derecho colectivo de los pueblos indígenas." (Gray 1996:264)

Hablando de las definiciones recientes y los intentos de catalogar a los indígenas, se sabe que en el caso chileno hasta la década de los 70, las legislaciones referentes a temática indígena se han referido meramente al recurso de tierra. A partir de 1972, en el gobierno de Allende, mediante la Ley 17.729 define por primera vez que los indígenas en territorio

\footnotetext{
${ }^{18}$ El caso de Canadá por ejemplo, donde se diferencia al "status indian", grupo de indígenas cuyas reservas habían firmado tratados con la Corona británica, los "metis" o mestizos y los "indian".
} 
chileno son "...aquellas personas que habitando del territorio nacional, formen parte de un grupo que se exprese habitualmente en idioma aborigen y se distingan de la generalidad de los habitantes de la república, por conservar sistemas de vida, normas de convivencia, costumbres, formas de trabajo o religión, provenientes de grupos autóctonos el país." (Ley 17.729 del 26 de septiembre de 1972 Art. 1)

El proyecto de ley original de la LI chilena enviado al Parlamento hablaba de "pueblos indígenas", pero en las discusiones en estas instancias este término fue objetado por ser "peligroso" para la unidad nacional y por temerse que la expresión "pueblo" implique como en el derecho internacional, cierto grado de soberanía política. La LI hace referencia a "indígenas", "culturas indígenas".

En Bolivia, el término "indio" se uso ( y se usa según el contexto) de manera peyorativa, tomando luego de la reforma agraria del 1953 el nombre de "campesinos". Posteriormente el movimiento indígena de las llamadas tierras bajas se reivindicó bajo la autodenominación de "indígena". La LPP boliviana se refiere a "pueblos indígenas", sin que esto en todo caso, haga referencia a una cierta "autonomía".

Para evitar malos entendidos, en el planteamiento que tuvo el gobierno boliviano de una ley indígena en 1991, que nunca fue aprobada, se aclara este punto haciéndose salvedad a "malos" usos del término "pueblos". "...es importante aclarar que cuando hablamos de pueblo, lo hacemos dentro de lo que es la identidad colectiva de un grupo humano; esto no significa cuestionar en ningún momento la soberanía política como muy bien lo especifica el Convenio 169..."(en Libermann 1991:61)

La LPP obligó para de la obtención de Personería Jurídica, a autodefinir la identidad grupal y hacerlo públicamente. Podían escogerse entre las identidades "campesinas", "indígenas"o en los casos urbanos mayoritariamente "Junta Vecinal" (aunque la población sea indígena). Ocurrió que por error (ya sea de autopercepción, o de definición por terceros ${ }^{19}$-con buenas o malas intenciones-) las comunidades campesinas estuvieron inscritas como comunidades campesinas o juntas vecinales y pocas como pueblos indígenas, a pesar de serlo. Derivó posteriormente en la limitación para acceder a ciertos derechos exclusivos de las poblaciones indígenas (como conformar un Distrito Municipal Indígena).

Hubo malas interpretaciones por desinformación de la gente de base y de los funcionarios municipales en definitiva, así en algunos casos, las organizaciones sindicales y organizaciones tradicionales de disputaron la categoría de inscripción de la personería jurídica (indígenas o campesinos). En otros casos, las organizaciones comunales no supieron bajo que nombre inscribirse ("Comunidad Indígena" o "Comunidad Campesina"20). Esta labor también dependió de muchas organizaciones de tipo gubernamental y ONG que promovieron y apoyaron el proceso de inscripción como OTBs.

\footnotetext{
19 Terceros como terratenientes de tierras bajas vieron afectados sus intereses al reconocerse los "pueblos indígenas" como tales, pues se les otorgaba derechos a reivindicación de tierras. Por otro lado, los alcaldes y demás mestizos involucrados en el Municipio tomaron negativamente el hecho de tener que lidiar con autoridades indígenas de forma horizontal.

${ }^{20}$ Especialmente en la zona andina, población aymará y quechua solicitaron su inscripción como "comunidad campesina", por su actividad agrícola.
} 
El término "pueblo" hace referencia a cierta autonomía indígena dentro del Estado (sin que implique soberanía política ni independencia), que algunos países, incluidos los de estudio, no quieren reconocer. En ambos casos, tanto en Chile como en Bolivia, al existir políticas de "discriminación positiva" y otorgárseles a las poblaciones indígenas derechos que los no indígenas no poseen (como acceso y tenencia legal de tierras, becas de estudios, proyectos prioridades de desarrollo, etc.), muchos indígenas que antes no se reconocían como tales por miedo a la discriminación, pasaron a reconocer su identidad étnica públicamente. También ocurrió que individuos no indígenas (sin ascendencia indígena, sean colonos o habitantes permanentes de zonas reconocidas como originarias) pasaron a autodefinirse como indígenas para acceder a los derechos y beneficios otorgados por ambas leyes. ${ }^{21}$

\section{iii) Tierra contra Territorio}

Mientras que "territorio" se refiere a grandes espacios geográficos, "tierra" hace referencia a una propiedad menor que generalmente se ocupa y explota individualmente. El Convenio 169 de la OIT reconoce el derecho a territorio y no solamente a la tierra indicando que "...la utilización del término "tierras" en los artículos 15 y 16 deberán incluir en conceptos de territorio, lo que cubre la totalidad del hábitat de las regiones que los pueblos interesados ocupan o utilizan de alguna manera." 22

En el caso boliviano, el mismo proyecto de una ley indígena que trabajó el Gobierno de Paz Zamora (1990-1995) conceptualiza claramente lo que se entiende por "Territorio Indígena" para no causar malos entendidos. "No se trata de un territorio con soberanía política, se trata de un territorio sin Estado, que entra bajo la gestión y administración política, social, y económica de los pueblos indígenas que lo habitan." (en Libermann 1991:61)

La Constitución y las leyes bolivianas actuales no hablan de territorio, sino de Tierras Comunitarias de Origen (TCO), donde son definidas como “... los espacios geográficos que constituyen el hábitat de los pueblos y comunidades indígenas y originarias, a los cuales han tenido tradicionalmente acceso y donde mantienen y desarrollan sus propias formas de organización económica, social y cultural, de modo que aseguran su desarrollo. Son inalienables, indivisibles, irreversibles, colectivas, inembargables, e imprescriptibles." (Ley INRA Art.41)

La LPP se refiere solamente al tipo de organización que debe haber a nivel local y como mencionamos ya, lo denomina Organización Territorial de Base, sin hacer alusión más especifica acerca del territorio, menos a los recursos naturales allí existentes, ni al derecho de tenencia de estos. El tema territorial es tocado bajo los puntos referidos al Municipio, es decir el Municipio como el territorio y base de la planificación y ejecución de planes y proyectos, mientras que en otros niveles se refiere a los Distritos Municipales Indígenas (y

\footnotetext{
21 Por ejemplo en la Ley Indígena, el caso de los "urbanos" santiaguinos que pasan a reconocerse como indígenas especialmente para acceder a créditos productivos y becas escolares, y en el caso de la Amazonía, individuos no indígenas acceden, mediante su "nueva identidad" a derechos de territorio y proyectos productivos, principalmente.

22 Dicho Convenio no fue aprobado en Chile porque el Congreso Nacional (diciembre de 1990) reparó la "inconstitucionalidad" de reconocer en carácter de "pueblos" a los indígenas y por la amenaza que significaba al derecho de propiedad el hablar de "territorios indígenas"(CONADI pp66).
} 
Distritos en general) haciendo referencia a la "continuidad geográfica" de las organizaciones territoriales y la "unidad territorial" en la que se ejecuta la prestación de servicios públicos.

En general, se puede decir que la Constitución boliviana mediante la Ley INRA, da a los indígenas seguridad sobre sus tierras y los recursos allá existentes, sin embargo, de manera implícita, "...se niega la posibilidad de administraciones locales autónomas, que en un país de mayorías indígenas pudiera poner en peligro y gobernabilidad e integridad nacional." (Vadillo 1997:325)

La ley chilena es mucho más específica en el tema de la tenencia y derechos sobre la tierra, no tanto así de sus recursos. Así, el Titulo II de la ley, se denomina "Del reconocimiento, protección y desarrollo de las tierras indígenas" tratando en sus 11 artículos detalladamente acerca de los derechos y el acceso a tierras y el Fondo de tierras y agua.

La ley hace referencia primeramente a cuáles son las tierras indígenas y cómo el Gobierno las protege. Se le da un tratamiento como tierras particulares, generalmente pertenecientes a familias, pero no a comunidades enteras. En el Art. 19 se refiere a "espacios territoriales conjuntos" que sean de propiedad fiscal como las canchas de nguillatún, apachetas y campos deportivos y avala su uso comunal.

El Fondo de tierras y agua, que administrado por la CONADI pasarán a encargarse de otorgar subsidios para la adquisición de tierras y financiar soluciones para problemas de tierras. La LI se refiere siempre al término "tierras", descartando la palabra territorio, no sólo por la discusión parlamentaria que anuló este término de la Ley, sino por la propia característica de la tenencia de tierra indígena en Chile de tipo más bien parcelada y no en grandes extensiones a manera más bien de territorio.

Indirectamente (o implícitamente) se plantea la necesidad de un territorio ancestral como base del desarrollo, así, en el Art. 26 al referirse a las características que deben haber para existir una Area de Desarrollo Indígena (ADI), se refiere a que podrá crearse una en

“...espacios territoriales donde han vivido ancestralmente las etnias indígenas” en miras de focalizarse recursos político y jurídicos.

\section{iv) De la Organización social}

Si la ley boliviana faculta a los indígenas a asociarse mediante la OTB (Art. 6) y las "Asociaciones comunitarias" o agrupación de OTBs (Art. 9) en función a su territorio con el fin de permitir la participación formal de éstos en planes municipales principalmente, la LI lo hace para cualquier fin y es más, restringe el derecho a la participación (visto como el que sean escuchados y se considere su opinión) solamente a las "organizaciones indígenas que reconoce esta ley" (Art. 34).

La LI chilena, para formalizar y facilitar (o burocratizar al igual que la ley boliviana a través de Personerías Jurídicas) la participación indígena, crea las "Asociaciones indígenas" que son la "asociación voluntaria y funcional integrada por a lo menos veinticinco indígenas que se constituyen en función de algún interés y objetivo común...” (Art.37L.I.) Esta Asociaciones, sin embargo, no podrán atribuirse la representación de las Comunidades 
indígenas ni podrán mancomunarse en el caso de una ADI, acción que podría fortalecer la organización a nivel macro y como consecuencia influir en la gestión de estas.

En ambos casos se deberán cumplir trámites de inscripción con respaldo político y una vez obtenidos los documentos de Personería Jurídica son reconocidos formalmente por el Estado como beneficiarios y participes de desarrollo.

Mediante los mecanismos citados, por un lado, el Estado posee control (por definición y por otorgación de derechos) de quienes son legalmente ciudadanos (indígenas como individuos y como organizaciones), pero por el lado de los indígenas sucede que se ven obligados a relacionarse con la sociedad nacional existiendo "legalmente" y debiendo haber cumplido trámites que antes eran inexistentes, así como también lo eran los beneficios.

El Estado boliviano, mediante la LPP pretende, para algunos detractores de la LPP, más que beneficiar a los pobladores rurales, sumergirse en su mundo antes olvidado para operar con mayor control sobre estos, además de someterlos a mayores obligaciones (cumplir trámites, solicitar permisos, etc.) y pasar a ser más dependientes del Estado en su calidad de benefactor.

La LPP respeta a la organización tradicional en general y reconoce legalmente y como sujetos de la Participación Popular y por lo tanto representantes de las Organizaciones Territoriales de Base (OTB) “...los hombres y mujeres, Capitanes, Jilacatas, Curacas, Mallkus, Secretarios(as) Generales y otros(as), designados según usos, costumbres o disposiciones estatutarias." (LPPArt.3 II)

Si bien, mediante la ley se reconocen los derechos de las poblaciones indígenas a organizarse de acuerdo a usos y costumbres, las organizaciones indígenas tradicionales muchas veces pierden paulatinamente la práctica de sus costumbres organizativas tradicionales y tienden a desestructurarse "para entrar dentro de la lógica político partidista y burocrática de la Participación Popular”. (Lema 2000)

El fenómeno de desestructuración de instancias de poder tradicional y disputa de poder y status de la viejas autoridades con los nuevos dirigentes avalados por las nuevas leyes, ocurrió en ambos casos. Por un lado, la ley chilena al reconocer las Asociaciones y las Comunidades Indígenas de forma legal, reconoció nuevas autoridades que en su mayoría de casos fueron jóvenes "letrados" que se desenvolvían bien con el mundo occidental (Aylwin $00)$.

Lo mismo ocurrió en el caso boliviano al elegir representantes de las OTBs y en ambos casos, las autoridades tradicionales, generalmente gente adulta, quedó relegada en la práctica, gracias a las leyes, que pretendían supuestamente revitalizar y aceptar las autoridades indígenas de manera formal.

Tanto en el caso chileno, como en el boliviano, se puede decir que existen diferencias de distribución y ejercicio de poder entre la lógica urbana, mediante la cual esta hecha la ley y la lógica indígena de detención y práctica del poder. Muchas veces las autoridades originarias perdieron prestigio al asumir funciones que indica la ley, y otras prefirieron 
delegar cargos a dirigentes de inferior importancia. En algunos casos, la ley permitió que los cargos se duplicaran y que exista un poder paralelo, lo que ocasionó más de un malentendido, pugnas por el liderazgo y/o vacíos de poder.

\section{v) Objetivo de las leyes}

La LI, es dentro de la historia de la legislación chilena, la que mejor trata la temática indígena de manera integral, haciendo referencia permanente a la cultura indígena, a sus valores y no solamente al tema de tierras, como las anteriores legislaciones.

Así como el principal objetivo de la ley es como su nombre dice la "protección, fomento y desarrollo" de los pueblos indígenas, el tema de la regularización de agua y tierras pasa a ser la base de este objetivo. “... en el curso de nuestro mandato presidencial, esperamos regularizar la propiedad de las tierras y aguas, asegurando de ese modo, a las comunidades, las posibilidades ciertas de desarrollo." (R. Lagos, mayo 2000) Esta ley permitió en la práctica alimentar sentimientos étnicos, fortalecer la conciencia étnica, orgullo étnico, reconstruir costumbres olvidadas y frenar procesos de aculturación. (Foerster 1999)

Otro objetivo de la ley fue abolir cualquier tipo de discriminación “...permitiendo a las personas que, junto con ser chilenas, sean parte de una cultura originaria, lo puedan expresar con toda libertad y claridad. Pensamos que de esta manera profundizaremos la vida democrática de nuestra sociedad."(Historia de la LI,BC 1997)

Para Andueza (1997) la LI no poseería un enfoque conservacionista, al favorecer ésta expresamente el desarrollo de los pueblos autóctonos. Se trataría más bien de un modelo de desarrollo "... que no viene impuesto unilateralmente desde el estado sino que es el fruto de un trabajo compartido y negociado con la comunidad local." Para el citado autor, las políticas desarrollistas que inspiran la LI chilena garantizan la “...subsistencia de culturas que de otra manera estarían llamadas a la marginalización y muerte dentro de una sociedad cada vez más globalizada e interdependiente."

Si bien, estamos de acuerdo que la LI no se encuentra dentro de un enfoque conservacionista, por abrirse de cierta manera a otorgar derechos que anteriormente no se habían dado a los indígenas, también creemos que el hecho de haber dejado de lado conceptos como "Territorio", "Pueblo Indígena", al momento de la aprobación de la ley, se favorece una forma de marginación y refleja una falta de trabajo compartido y una mala negociación de parte de la comunidad local, donde obviamente debieron estar representantes de las comunidades indígenas interesadas.

Los instrumentos planteados por la ley chilena para cumplir sus objetivos de desarrollo son el Fondo de Desarrollo, el Fondo de Tierras y Agua y las Areas de Desarrollo Indígena. Estos instrumentos son bien delimitados y regulados y se enfocan de manera general más en el aspecto relacionado con la tenencia de la tierra que en el segundo tema que legisla esta ley: el respeto y protección de la cultura indígena. 
Por su parte, el objetivo principal de la LPP boliviana ${ }^{23}$, como bien su nombre lo indica, es articular a la ciudadanía en general, y comunidades indígenas, campesinas y urbanas en particular, a la vida jurídica, política y económica del país, mediante la participación de diferentes niveles de la sociedad, tanto de hombres como de mujeres, en una mejor distribución y administración de los recursos públicos.

La descentralización es aspecto fundamental de esta ley. Así se destina $20 \%$ de los ingresos del Estado a ser repartido por el número de personas habitantes en los diferentes Municipios y no como anteriormente se hacía, entre los tres principales centros urbanos de Bolivia (La Paz, Santa Cruz y Cochabamba). Así mismo el $42 \%$ del total de los bolivianos residentes en zonas rurales se beneficiarían por primera vez de recursos del Estado de forma directa y sería reconocida jurídicamente su organización.

Con la LPP, se otorga la responsabilidad del desarrollo (económico cultural y social) a los 311 gobiernos municipales, muchos de ellos nacieron luego de dictada la ley particularmente en zonas donde anteriormente la presencia estatal era poca o nula. Se incrementa la presencia del Estado en las zonas rurales, pero también se incrementan recursos económicos que nunca antes habían sido vistos en dichas zonas.

La práctica de la democracia parece ser en este sentido la base de la LPP, reflejada en el alto grado de participación ciudadana en decisiones en las inversiones y actividades del Municipio. Otra característica de esta ley es además el respeto a las diferencias étnicas y de tipo socioeconómico, respetando "lo local" en relación a "lo centralizado". Así la vida de los Municipios del área rural toma una nueva alternativa de gestión y planificación de alguna manera independiente del poder central, lo que no había ocurrido hasta ese entonces.

Como instrumentos jurídicos para llevar a cabo sus objetivos y para viabilizar la participación se plantea la creación de las OTBs, organización e los Comités de Vigilancia y la Distritación Municipal a modo de hacer más práctica la redistribución de recursos.

Los habitantes comunes podrán, a partir de la puesta en marcha de la Ley, participar en la vida jurídica y económica del país y acceder formalmente a derechos estatales, mediante la otorgación de personería jurídica. Por otro lado mediante la constitución de Organizaciones Territoriales de Base (OTB) o Asociaciones de OTBs se obtiene el derecho a aprobar la ejecución de obras del municipio en beneficio propio, además del derecho de solicitar o priorizar proyectos basados en necesidades grupales. ${ }^{24}$

Buscando la participación ciudadana en campos de la administración pública, a partir de la ley, los pobladores indígenas, pueden intervenir, a través de los comités de vigilancia (CV) en instancias de planificación y administración del municipio, ejerciendo su derecho de control y vigilancia. Las políticas del Viceministerio de Participación Popular en el marco

\footnotetext{
${ }^{23}$ Ley Nr.1551 del 20 de abril de 1994. Esta Ley se complementa con la Ley de Municipalidades (Nr.2028) del 28 de octubre de 1999.

${ }^{24}$ Si bien, mediante una resolución el gobierno de turno se comprometió en 1996 a constituir una comisión conformada por representantes del gobierno y de las organizaciones indígenas y campesinas, con el propósito de una modificación al régimen de Municipios Indígenas dentro de la Ley Orgánica de Municipalidades, esta ley solamente menciona a los DMIs tal y como son tratados en la LPP, sin hacer referencia a "Municipios Indígenas" como eran demandados .
} 
étnico, por lo tanto, se relacionan con el reconocimiento de los pueblos indígenas y sus organizaciones y su participación en gestión del desarrollo paralelamente al reconocimiento de su cultura dentro de este proceso.

El principal instrumento de la LPP para lograr este fin -cuyo análisis es el propósito de este trabajo- es la creación de Distritos Municipales Indígenas (DMIs), diferenciados de los otros Municipios por ser delimitados a áreas indígenas históricas, se reconoce así el espacio que habitan los pueblos indígenas, articulando la gestión pública con la gestión territorial. La figura de la Mancomunidad de Distritos, pretende poner fin al fraccionamiento de territorios étnicos (en diferentes cantones, provincias, y departamentos), resultado de las políticas de división geográfica.

Mediante estos mecanismos jurídicos, se busca que las soluciones a las demandas de los pobladores no lleguen desde arriba (Estado mediante municipio), sino se busca la participación de éstos en el proceso, además de buscar también la relación más fluida entre los pobladores indígenas, sus organizaciones y el municipio.

Los cambios de la participación popular “...consistieron en una singular combinación de descentralización del estado y democracia participativa diseñadas para abordar los problemas de desarrollo institucional, de la política rentista y de la integración nacional en forma directa desde abajo." (Oxhorn s/f) La etapa de transición de un gobierno (planificador y ejecutor de la Ley con Sanchez de Lozada (1993-1997) a otro nuevo y además opositor (Banzer 1997-2002), sin duda ha retardado el desarrollo de la práctica de esta ley y han habido pequeñas variaciones en su puesta en marcha.

En síntesis, según Lema (2000), La Participación Popular, a seis años de su puesta en marcha podrá: introducir a los indígenas en la modernidad y prácticas burocráticas de ciudadanía o crear resistencia al estado y sus políticas y solicitar políticas diferenciales y de discriminación positiva. El mismo dilema, a nuestro parecer, de la LI en Chile.

Ambas leyes están inmersas dentro de la corriente de legislación internacional que reconoce solamente ciertos derechos (culturales y económicos principalmente), no así derechos políticos como la autonomía o autogestión que si son mencionados por ejemplo en el Convenio 169 de la OIT.

\section{vi) Descentralización y focalización para un desarrollo indígena}

En Bolivia un primer intento de descentralización administrativa relacionado a la gestión indígena se planteó en un Proyecto de Ley Indígena Nacional en 1991. Uno de los objetivos de esta supuesta Ley hubiera sido "contribuir al proceso de descentralización política y administrativa que está viviendo nuestro país." (Riveros en Libermann 60)

La intención descentralizadora a nivel general y como está planteada en la LPP, tiene dos vertientes . Por un lado como política desconcentradora con objetivos administrativos, buscando eficacia y eficiencia en la entrega de servicios adecuados recortando pasos burocráticos, y, por el otro, busca una mejor administración con otro propósito de fin político -administrativo además, para así crear oportunidades adecuadas “...que faciliten la 
incorporación responsable y participativa, de la iniciativa de los usuarios a los cuales se dirige la política.” ( Salazar 1998)

A pesar de que la idea de descentralización se relaciona a la aproximación entre la toma de decisiones de manera local, donde surge la demanda social, se trata además de una búsqueda de eficiencia para el aparato burocrático. La descentralización buscaría profundizar la democratización en los procesos de gestión pública. Se busca repartir por igual el poder estatal y además los beneficios del desarrollo económico.

Por un lado la ley chilena prioriza la tenencia legal y consolidación de territorios indígenas (aunque no contemple siempre la tenencia comunal de tierras) y busca la restitución de territorios históricos mediante la adquisición de tierras demandadas de parte de la CONADI, mientras que en Bolivia, mediante la Ley se intenta darles derechos comunales y/o grupales en relación a su forma de asentamiento y uso territorial, reflejados claramente en lo que la ley ha priorizado para su participación como las OTBs.

La política de focalización de Chile se debe a que la población indígena dentro del contexto nacional se encuentra distribuida en zonas específicas (Regiones I, II, VIII, IX, X y RM) hasta donde las políticas sociales han llegado sin diferenciarse del resto de la población, tomándose en cuenta como áreas pobres y de extrema pobreza. Lo que se intenta hacer mediante los proyectos sociales con enfoque culturalista fomentados por la CONADI, como mencionamos ya, es una lucha contra la pobreza en zonas indígenas, además de prevenir conflictos de carácter étnico como los que ocurren frecuentemente en los territorios mapuche con el objetivo de reivindicar tierras expropiadas.

\section{vii) Fortalezas y obstáculos de las leyes en la promoción del desarrollo indígena}

Se supone que estas leyes deberían ser por sí mismas "promotoras del desarrollo indígena". Formal y legalmente poseen aspectos que facilitan este desarrollo. En la práctica, empero, por diversas razones, como la falta de difusión de las mismas, mal entendimiento de éstas, falta de voluntad política, intereses de terceros para no llevar a cabo el fin de las leyes, etc., podrían convertirse en un obstáculo para el desarrollo indígena o en instrumentos innovadores que no influyan en lo más mínimo para que este ocurra.

La LPP posee tres instrumentos que podrían tomarse como legalmente establecidos para fomentar el desarrollo indígena a saber: las OTB, los Comités de Vigilancia (como instancias de participación) y los Distritos Municipales Indígenas. La LI tiene como instrumentos facilitadores del desarrollo los tres fondos citados anteriormente, el Fondo de desarrollo, el Fondo de tierras y agua y las Areas de desarrollo indígena.

\section{a) Fortalezas}

Mediante estas leyes se intenta poner fin a un marginamiento histórico de parte del Estado, reconocer pública y formalmente la existencia de población indígena en los territorios nacionales, y a la vez facilitar su participación en decisiones relacionadas con "su desarrollo". 
Las leyes otorgan derechos a pobladores en general (caso LPP) y pobladores indígenas en especial (ambas leyes) nunca antes conferidos. Se busca la preservación de las estructuras culturales y organizativas ya existentes, además de fortalecerlas.

En el tema territorial, ambas leyes enfocan como prioritaria el tema para un desarrollo económico y social, pero tiene diferentes enfoques hacia el tratamiento de este recurso. Mientras para la ley boliviana el concepto de "territorio de base", se relaciona al modo de percibir un territorio como base de su planificación para el desarrollo; en el caso chileno focaliza mucho en el acceso a la tierra (de manera más bien individual que comunal) y la legalización de éste. En Chile una gran fortaleza de tipo económico fue la priorización del tratamiento a las tierras indígenas, su ampliación, protección, apoyo a la defensa en litigios sobre tierras.

Siempre, respecto a la ley chilena, hay que destacar como fortalezas los instrumentos para llevar a la práctica su objetivo, como lo el Fondo de tierras y aguas, Fondo de desarrollo indígena, Registro de tierras y aguas indígenas, acreditación de la calidad de indígena y Areas de Desarrollo indígena, estos últimos concebidos como focalización de programas de inversión social y productivo.

En el tema socio-cultural, la LI tiene tiene más fuerza, ya que se aglomeran los derechos indígenas a preservar su cultura, a utilizar lenguas propias, a practicar su cultura y preservar sitios sagrados y cosmovisión, etc. y estos derechos se hacen explícitos. En cambio la LPP el tratamiento de derechos socio-culturales es indirecto y no se le da tratamiento integral al fortalecimiento y respeto de la cultura. La LPP, sin embargo, reconoce como sujetos de participación popular a comunidades indígenas, pueblos indígenas, comunidades campesinas existiendo un reconocimiento tanto en el campo del derecho privado, como también propone mecanismos para lograr participación en instancias de administración publica mediante OTBs, CV y DMIs, etc.

Si en ambos países el trato discriminatorio de la población nacional en relación a la indígena trajero como resultados conflictos de identidad (del hombre rural con anhelos de "blanquearse" y urbanizarse), las leyes LPP y LI revierten esta tendencia y fortalecen las identidades étnicas, sea por una cuestión de "sentimiento cultural y reivindicativo" o por aspectos más bien por un lado de beneficio personal y por otro a nivel étnico-grupal.

En ambos casos, el chileno y el boliviano, la historia de la República (basada en prácticas coloniales), lo que había buscado era cercenar los territorios étnicos históricos, la nuevas Leyes pretenden respetarlos y fortalecerlos, como base del desarrollo indígena. La LI mediante la búsqueda de restitución y protección de las tierras indígenas (no del territorio) y la LPP mediante los Distritos Municipales Indígenas y su delimitación en base a territorios étnicos históricos.

A nivel de recursos naturales, ambas leyes protegen el uso de recursos naturales en territorio indígena como parte del desarrollo de las comunidades. La Ley chilena complementa su enfoque de protección de tierras con el uso y acceso legal a aguas. Sobre el derecho a otros recursos naturales del suelo y subsuelo se habla poco. 


\section{b)Obstáculos de las leyes para la promoción del desarrollo indígena}

-Si bien ambas leyes representan una nueva y gran oportunidad de participación indígena en su desarrollo, los indígenas se enfrentan por primera vez a dos grandes barreras ideológica y práctica, que pueden ser consideradas problemas inherentes a las mismas leyes (Lema 00).

Por un lado para aplicar las disposiciones legales es necesario que el sector indígena adopte desconocidas y complicadas prácticas institucionales (como la conformación de grupos, organizaciones, asociaciones, elección de representantes, inscripción formal de estas organizaciones, etc.).

Luego, un segundo problema se relaciona con la información acerca de las nuevas leyes, sus derechos y obligaciones con varios capítulos y muchos artículos, van difundidas en idioma español, y no sólo esto, sino en español con matices jurídicos, lo que hace que poca gente entienda realmente de que tratan las leyes y cómo estas les favorecen. En este sentido los dirigentes "letrados" han jugado un papel importante en la difusión y entendimiento de las leyes.

-Las no leyes reconocen en ningún caso la independencia de tipo política en relación al poder central, aunque en el caso boliviano los ciudadanos tengan derecho a participar en la programación del presupuesto municipal y objetar las inversiones de estas instancias.

Al haber recursos económicos destinados a financiar para programas basados en las inquietudes y necesidades de los indígenas, la LPP y la LI tienen legalmente grandes fortalezas para promocionar un desarrollo indígena. Pero no basta el derecho a la participación y los recursos, sino compromiso y capacidad de gestión que no están garantizados en las legislaciones.

Debe recordarse que los beneficios materiales tales como inversiones municipales en infraestructura escolar, de salud, deportiva, de áreas verdes, proyectos productivos, etc., no deberían ser la evidencia de una buena puesta en marcha de la ley.

-La LI reconoce las Asociaciones Indígenas sin reconocer formalmente a las autoridades originarias, lo que podría ser un obstáculo para la vigencia de las autoridades tradicionales. Como mencionamos anteriormente, en ambos países a partir de éstas se crean nuevas autoridades diversas que las tradicionales, lo que da como resultado poderes paralelos y competitividad.

Las nuevas políticas bolivianas y la LPP en sus origenes pretenden institucionalizar nuevas formas de decisión y ejecución en base a organizaciones sociales ya existentes, y no sobre ellas (Vadillo 97). El hecho de "respetar organizaciones ya existentes" ha causado conflictos en la práctica cuando se disputan legitimidad política y/o representatividad entre el sindicato y las organizaciones tradicionales, lo que mencionamos también ocurre en el caso chileno con las autoridades nuevas de las conformadas "asociaciones" y "comunidades indígenas" para obtener una Personería Jurídica que desplazan a los antiguos representantes tradicionales. 
En el tema socio-cultural en el caso de la LPP, los resultados de la Ley podrían se cierta manera ser comparados con los resultados de la Reforma Agraria del 53 (Oxthorn s/f). En la práctica no han sido significativos para los indígenas necesitados y campesinos por no haber sabido acceder a los derechos y no tener la capacidad de asimilarlos y practicarlos.

-Al poner en práctica le LPP, se pretende institucionalizar la democracia (como medio de organización y de ejercicio de derechos), pero en la realidad, este sistema no es siempre practicado a modo de costumbre tradicional. El caso del pueblo Guaraní, por ejemplo ${ }^{25}$, no practica una democracia en la elección de sus autoridades, sino, los cargos son hereditarios familiarmente.

-La LI prioriza el tema de protección y restitución de tierras indígenas, la identificación de las tierras indígenas de manera individual, creemos es parte de su percepción del tema, además de haber sido tratado así a lo largo de la historia. Chile habla de tierras indígenas, por que formal y legalmente los indígenas chilenos poseen tierras y no territorios

-En la práctica, se debe reconocer que la LI no otorgó ninguna clase de respaldo en el ejemplo del conflicto por la construcción de la Hidroeléctrica Ralco, a pesar que en 1997 ya se había declarado la zona como el Area Indígena Alto Bio Bio.

\footnotetext{
${ }^{25}$ El caso de la Capitanía de Kaipependi Karawuaicho y del Isoso, ubicados en el Departamento de Santa Cruz y conformados como Distritos Municipales Indígenas.
} 


\section{Capítulo 3)}

AREAS DE DESAROLLO INDÍGENA Y DISTRITOS MUNICIPALES INDÍGENAS: El desarrollo indígena desde el Estado

Como vimos anteriormente, las leyes que comparamos tienen enfoques diferentes y, para afrontar el tema indígena y el desarrollo socioeconómico de este sector poblacional y en consecuencia poseen diferentes metodologías y objetivos. Nuestro objeto en este capítulo será el estudio los instrumentos (tanto jurídicos como prácticos) que disponen las leyes, a saber, por un lado, el Fondo de Tierras (FT), Fondo de desarrollo (FD) y Areas de Desarrollo Indígena (en adelante ADIs) en el caso chileno y, por otro lado, los Distritos Municipales Indígenas (en adelante DMIs), en el boliviano.

Ya habíamos mencionado que la situación de pobreza es una característica en zonas con predominancia de población indígena, tanto urbana como rural (Psacharopoulos/Patrinos 94, Plant 98 y otros). Como otros gobiernos en Latinoamérica, los dos gobiernos del estudio, pretenden paliar la pobreza en zonas indígenas mediante la implementación de políticas directas entre las que se encuentran estas figuras. Se trata, entonces, en ambos casos de un intento de mejor distribución de recursos estatales que antes no llegaban a estas zonas postergadas. ${ }^{26}$

Chile y Bolivia pretenden este objetivo, junto con el respeto de la identidad indígena, focalizando el desembolso de recursos en zonas indígenas. Se cree que cumpliendo objetivos de tipo económico-productivo se logrará sacar a los indígenas de un cierto grado de marginación, especialmente en miras de la inversión en infraestructura y servicios básicos. Pareciera que los Estados pretenden poner en práctica como si fuera lo mismo, las "políticas contra la pobreza" y la promoción de los "derechos indígenas". Es así como tratan esta problemática en el uso de estas figuras legales.

Para el análisis de la ADIS y DMIs, su planteamiento y funcionamiento, hemos dividido en cuatro áreas temáticas principales que a nuestro parecer engloban la problemática analizada.

Comenzamos con la descripción de la esencia de las figuras legales y sus objetivos tal como están planteados en las leyes, para seguir luego con el análisis de la metodología y estrategias utilizadas para el desarrollo regular de las instituciones estudiadas. El tema del tratamiento estatal de la territorialidad es de primordial importancia en el análisis de las figuras, por lo que en tercer acápite tratamos esta temática. Por último, analizamos la gestión y participación indígena tanto en las ADIs como en los DMIs, tratando además de estos temas, el de los recursos y la posible autonomía.

\footnotetext{
${ }^{26}$ Plant (1998:3) describe las posiciones contrarias de algunos Estados a enfocar la pobreza desde un punto de vista étnico, porque indígenas comparten un mismo territorio con pobladores no indígenas, y porque esta diferenciación étnica en la promoción del desarrollo puede promover tensiones interétnicas a nivel de todas la sociedad.
} 


\section{i) Contexto y objetivos de ambas figuras legales}

En la discusión de la ley 19.253 en el Congreso chileno, la figura de las ADIs sufrió varios cambios desde su original concepción. El borrador de la LI (julio-septiembre de 1990) hablaba de "Territorios de desarrollo Indígena" definidos como “...espacios social, demográfico, ecológico, cultural, fundamental para la existencia y el desarrollo de los pueblos indígenas".(Discusión de la LI, B.C. 1997). Estos territorios estaban pensados como "unidades básicas de planificación para implementar planes y programas de desarrollo de esas áreas tales como agroindustria, industria, etc.”.(CONADI s/f pp9)

En un primer enfoque sobre las ADIs, este espacio estaba principalmente pensado como un área de desarrollo económico de los pueblos Indígenas, pero también como protección al medio ambiente. Se pretendió tomar "el desarrollo socioeconómico y la protección ecológica como dos cuestiones inseparables." (2do informe CEPI en CONADI 99),

Tras una discusión en el Congreso perduraron en la ley criterios como "homogeneidad ecológica" y "dependencia de recursos naturales para el equilibrio de los territorios" necesarios para la conformación del ADI. (Art. 26)

El reemplazo de la palabra "territorio" por la de "área" fue argumentado en el sentido de que "territorio " era un concepto utilizado en la Constitución de 1980, en el tiempo del gobierno militar para referirse al "territorio nacional". Se utilizó finalmente el término "área" al no tener connotación relacionada al ordenamiento jurídico. El hecho de descartar el uso de "territorio" (siguiendo la definición de NNUU) tras una larga discusión parlamentaria, demuestra los temores de una parte de la sociedad chilena "... que ve en el uso del término "territorio indígena" una amenaza a la integridad y unidad nacional y antesala a los procesos de autonomía indígena."(Molina en Revista CONADI 1997:17)

Por su parte, en Bolivia existe la figura de Distritos Municipales de forma general desde 1985 reconocidos por la Ley Orgánica de Municipalidades. En el área rural boliviana, los DMIs se diferencian de los Distritos Municipales productivos o ecológicos, figuras aún poco definidas en la ley y poco practicadas.

Mediante la nueva figura especifica de los DMIs, que mediante su metodología de "planificación participativa en zonas indígenas", permitiría dar un enfoque étnico al desarrollo, los indígenas serían por primera vez tratados de manera diferencial en instancias administrativas estatales.

La LI conceptualiza las ADIs de manera muy general y resumida como “...espacios territoriales en los que los organismos de la administración focalizarán su acción en beneficio del desarrollo armónico de los pueblos Indígenas y sus comunidades." ( Párrafo 2. Art. 26)

Para conformarse ADIs, deberán tomarse en cuenta algunas características como son espacios territoriales ancestrales de etnias indígenas (como vimos anteriormente la LI especifica claramente quiénes son indígenas), alta densidad poblacional indígena (en un principio se especifico que esta población debería tener características de extrema pobreza), 
existencia de tierras, comunidades o individuos indígenas, predominancia de tierras indígenas, homogeneidad ecológica y dependencia de recursos naturales.

La Ley de Participación Popular boliviana reconoce los Distritos Municipales de manera general como "unidades administrativas y de ejecución desconcentrada del gobierno municipal, integradas territorialmente y dirigidas por un subalcalde" (Art. 26 Titulo V) siendo sus objetivos la promoción de la eficiencia de la acción interinstitucional en el manejo de políticas públicas, promoción de la gestión administrativa en el ámbito territorial, la promoción de la participación de OTBs en la administración y planificación del desarrollo regional y la mantención de la unidad socio-cultural de las organizaciones de carácter territorial dentro de la jurisdicción del distrito.

Los Distritos Municipales Indígenas son reconocidos de forma especifica en su Art. 17 que indica que "...en los lugares donde exista una unidad geográfica, sociocultural, productiva o económica menor o mayor a un cantón, el Gobierno Municipal aprobará la creación de un Distrito Municipal y la designación de un(a) Subalcalde". Los distritos son por lo tanto, unidades de gestión menores a los Municipios y dependientes de las decisiones y de los recursos de estos.

La figura de los DMIs surge con dos principales objetivos: de forma prioritaria a modo de agilizar y volver eficiente la administración municipal a nivel regional en todo sentido y, complementariamente, como forma de acceso a derechos y reivindicaciones indígenas de participación en instancias y decisiones estatales.

La LPP indica en torno a los DMIs que estos son: “...unidades administrativas y de ejecución desconcentradas del Gobierno Municipal, integrados territorialmente, dirigidas por un Subalcalde...”. Tienen por objetivo la promoción de la acción intersectorial en políticas públicas y manejo de recursos, la promoción de la eficacia de la gestión administrativa descentralizada del Municipio y la promoción y articulación de las Organizaciones Territoriales de Base. La característica étnica se refleja en el hecho que mediante esta figura se pretende "...mantener la unidad socio cultural de las organizaciones sociales de carácter territorial dentro de la jurisdicción del distrito...". (DS 23858, 1994 Art. 26)

La Distritación Municipal puede ser vista como “...el encuentro entre los que brindan los servicios (oferta social por parte del Estado) y los que demandan (demanda social).Para un mejor resultado, esta negociación deberá realizarse en los mismos ámbitos territoriales en sus diferentes escalas".(Romero 99:106)

Aprobada posteriormente, la Ley 1702, habla de Distritos Multiétnicos que serán “... las unidades socio culturales constituidas como efecto de migraciones en centros urbanos o rurales y corresponden a una diversidad de culturas de uno o más pueblos o comunidades indigenas que puede comprender el área rural o urbana." 
La política boliviana de los DMIs, está inspirada principalmente en la descentralización administrativa (pretendía ser también de poder) para obtener mejor eficiencia en la gestión municipal, mientras que el caso chileno de ninguna manera tiene que ver con descentralización ni tampoco con gestión municipal. Las ADIs, más bien centralizan recursos de proyectos de desarrollo de varias instituciones pertinentes a modo de dotar a la población indígena de programas de desarrollo específicos.

No obstante, al tratarse de leyes nacionales, es que priorizan la inversión estatal, al crear entidades indígenas reconocidas formal y jurídicamente, se abre la posibilidad de búsqueda de financiamiento para programas y proyectos de desarrollo hacia otras fuentes como ser ONGs, entidades religiosas, etc. .

En el aspecto socio-político, si bien ninguna de las dos legislaciones promueve o reivindica la identidad étnica, ni atribuyen directamente a las comunidades derechos políticos ligados a un territorio determinado. Sostenemos que como resultado secundario se da este fenómeno, especialmente en el caso boliviano donde se parte de la organización tradicional para la planificación de planes de desarrollo. Los Distritos son pensados para desconcentrar la gestión e inversión municipal con un enfoque étnico. ${ }^{27}$

En el caso de Chile su relación con temáticas tales como "desarrollo indígena", junto con la educación intercultural, la entrega de becas, restitución de territorios históricos, etc., pudiera en el futuro asociarse también a gestión de territorio.

La figura de las ADIs surge en la LI como un modo de solucionar la extrema pobreza. El Fondo de Desarrollo Indígena (denominado en un principio Fondo de Etnodesarrollo) concretaría la "realización de planes y programas agropecuarios que tiendan a mejorar sustancialmente las condiciones de vida de los campesinos indígenas". (Discusión de la LI, BC 1997)

El Fondo de Desarrollo Indígena tiene por objeto "financiar programas especiales dirigidos al desarrollo de las personas y comunidades indígenas...". Por ejemplo a través de créditos, sistemas de capitalización y subsidios, enfocados principalmente al desarrollo económico, en el acceso a tierras indígenas y mejoras en la explotación de estas, además de la explotación de otros recursos como pesca y acuicultura para los indígenas en zonas rurales, y créditos y apoyo a la producción de todo tipo a indígenas de zonas urbanas.

Los principales objetivos de esta figura, tienen relación con el fortalecimiento de la cultura propia y adoptar medidas concretas para contrarrestar el debilitamiento de ésta, elevar el nivel y calidad de vida de los indígenas, promoviendo un "desarrollo culturalmente sustentable" entendido como "garantizar el derecho a los pueblos indígenas a definir los objetivos y medios propios de su desarrollo”.(MIDEPLAN 2000b)

\footnotetext{
${ }^{27}$ No siempre los beneficios de las leyes son palpables (como sería infraestructura, por ejemplo), sino en muchos casos de tipo simbólicos. Podemos mencionar por ejemplo que las identidades y autoadscripciones étnicas se ven fortalecidas. Este ha sido el caso de los Atacameños (en base al ADI Atacama la Grande, Chile) o a los Uru Iru Itu (del Municipio de Viacha, Bolivia).
} 
Como la creación de las ADIs pasan por el filtro oficial, el desarrollo socio económico podría beneficiar únicamente de la población indígena que la CONADI vea prioritaria. En efecto hay zonas que precisan ser declaradas y tratadas como ADI (por ejemplo el caso de San José de la Mariquina, Lago Ranco y Panguipulli en la X región además de Nueva Imperial en la IX) y sus poblaciones indígenas así lo han solicitado, este trato prioritario no se tomó en cuenta hasta la fecha.(Aylwin 00)

Pensando en una manera de mejor distribución de recursos con el fin de hacer más equitativo el acceso a servicios básicos, la creación de Distritos Municipales (en áreas urbanas y rurales) y DMIs en áreas rurales a petición de las propias poblaciones indígenas, permitiría destinar fondos para proyectos generados desde las bases en miras a solucionar las necesidades planteadas desde un enfoque propio. Son una instancia de administración pública para la planificación del desarrollo de sus comunidades o pueblos respetando rasgos socio-culturales.

A través de los DMIs la ley plantea salidas posibles a la tensión generada entre la necesidad de poder y decisión y la vigencia de autoridades tradicionales de los pueblos indígenas en su territorio. El papel principal de los indígenas en los DMIs sería la planificación y ejecución de proyectos y el control y gestión de los mismos, aunque la posibilidad de administración sea solo indirecta, ya que tanto política como económicamente los DMIs dependen del Municipio.

Por otro lado mediante los DMIs las unidades socio-culturales de los pueblos indígenas son reconocidas como unidades de "planificación territorial", lo que fortalece en gran parte a la preservación los territorios históricos y promueve el desarrollo de las unidades étnicas en su conjunto. El desarrollo indígena es posible teniendo como fortaleza el territorio y la organización tradicional, e indirectamente se sabe que se constituyó como un medio unificador de los grupos étnicos a nivel de organizaciones locales.

La constitución de los Distritos Municipales Indígenas es una manera que tiene es Estado de dar a los indígenas un tratamiento diferente y de reconocer la diversidad étnica y cultural, además es una manera estatal de "...invertir el principio de igualdad de oportunidades que en una sociedad desigual sólo fortalece la desigualdad económica y social, por el de atención diferenciada en función de resultados económicos y sociales más equitativos." (Vadillo1997)

Si bien, como reconoce este autor, se trata de una manera de "igualar las oportunidades", veremos en la parte destinada al análisis de la gestión y participación indígena, que a pesar de "existir la oportunidad de ejercer ciertos derechos", en la práctica se hacen difícil por variadas falencias de la misma ley (por ejemplo responsabilidades no muy bien definidas) o por carencia de capital social (pocos indígenas responden favorablemente al llevar a cabo la gestión de sus DMIs).

A través de los DMIs las unidades socio-culturales de los pueblos indígenas son reconocidas como unidades de planificación territorial. Principalmente el papel de los indígenas en los DMIs sería la planificación y ejecución de proyectos y el control y gestión de los mismos. 
Mediante las ADIs se plantea una solución a la falta de inversión social en zonas marginales con predominante población indígena. Así como los DMIs, estas figuras de la ley chilena son también unidades de planificación territorial para mejorar la infraestructura en general y dar prioridad programas de desarrollo socio-ecónomico. En las ADIs, la población indígena se reconoce solamente como beneficiaria de esta inversión, siendo la CONADI la que media su participación.

Las ADIs, como los DMIs son fruto de una búsqueda de parte del Estado del relacionamiento del desarrollo económico con el cultural. Si bien, en la figura de las ADIs no se especifica que el desarrollo debe tener un enfoque socio-cultural (principalmente al negar la participación indígena directa), la esencia de la LI así lo promueve y en la práctica los documentos ministeriales referidos al tema también toman la participación indígena como indiscutible y necesaria.

Un aspecto que se constituyó en una barrera para la creación de los DMIs fue el tener que lidiar con "oligarquías locales" que detentan poder en el área rural y que por intereses personales se negaban a apoyar el proceso. En el caso chileno pudieran haber intereses de terceros para la conformación de ADIs, como el caso del alto Bio Bio donde un grupo de terratenientes presentó un recurso de protección en contra del Presidente de la República ql no querer que sus fundos estén incluidos dentro del ADI por provocarles amenaza (MIDEPLAN 2000a). Esto podría ocurrir en otros casos futuros por ejemplo en la región sur en zonas de explotación forestal, terratenientes, ganaderos o en el norte con por intereses de inversionistas mineros.

\section{iii) Situación actual ${ }^{28}$}

A seis años de haberse puesto en marcha la LI en Chile, el proceso de creación y reconocimiento de ADIs ha sido lento, habiendo 3 ADIs legalmente establecidas en 1997: "Atacama la grande" (II Región), Alto Bio Bio (VIII Región) y Lago Budi (IX Región). La CONADI solicitó la creación de 7 ADIs nuevas ${ }^{29}$, que podrán ser en un futuro reconocidas como tales mediante un Decreto Supremo. Existe en discusión interna en la CONADI compartida por cientistas sociales, la opinión según la cual que los recursos deberían destinarse a reforzar y encaminar el proceso de desarrollo en las ya establecidas, antes de crear otras que por falta de gestión y recursos, no se traduzcan en experiencias negativas .

Las tres ADIs aprobadas legalmente vienen siendo en los últimos tres años apoyadas para su regular funcionamiento, mediante recursos, especialmente de tipo material, pero además es de suma importancia que mediante su instauración, han servido de base y ejemplo para la reformulación de instrumentos y propuestas metodológicas para llevar a cabo los objetivos de esta figura legal para futuras experiencias.

Se sabe que algunos DMIs bolivianos con población indígena fueron reconocidos como "campesinos", esto especialmente ya que los indígenas aymarás y quechuas de las zonas

\footnotetext{
${ }^{28}$ Ver en anexo Cuadro \# 6 y \#7 Situación actual de las ADIs y DMIs respectivamente

${ }^{29}$ Ver en anexo Mapas \# 2, \#3 y \#4 las ADIs establecidas y sus límites. Las ADIs solicitadas son: Isla de Pascua (indígenas Rapa Nui), Lleu Lleu (indígenas mapuche), Putre (indígenas aymará), Lonquimay (indígenas mapuche), San Juan de la Costa (indígenas mapuche), Puerto Eden (indígenas Kawashkar) y Bahía Mejillones (indígenas Yaganes).
} 
altiplánicas que se reconocen históricamente más con el término de "campesinos" que como "indígenas" o por otro lado debido a intereses políticos y económicos de los Municipios y de grupos locales poderosos.

La Ley Boliviana reconoce varios tipos de Distritos Municipales (DMs) que actualmente están vigentes y en funcionamiento (por lo menos reconocidos como tales). Junto con los 41 DMs ecológicos o de preservación ${ }^{30}$ (en Parques nacionales cuyo objetivo es la preservación del ecosistema), 47 productivos, 231 urbanos, y 686 rurales (principalmente donde se encuentran DMIs).

En el territorio boliviano hasta el año 2000 se habían conformado138 DMIs, repartidos en las zonas de Altiplano (88), Amazonía (29), Chaco (18) y Oriente (3). ${ }^{31}$ Muchos no pudieron crearse por la poca cantidad de habitantes (como los Machineri, Baure, Ayoreos, Pacahuara y otros), en muchos casos tuvieron que hacerse DMIs multiétnicos alcanzando una cantidad suficiente de pobladores para solucionar este problema.

Actualmente existen dos diferentes situaciones desde una perspectiva macro de los DMIs. Primeramente los creados formalmente (con Ordenanza Municipal inclusive) cuya existencia ha sido promovida por instituciones -estatales o no- ajenas al grupo y que los pobladores de este no consideran importante o ni saben para que sirve su conformación, la segunda situación es la de los DMIs han cumplido con la mayor parte de trámites para su conformación, pero por motivos burocráticos y de negligencia de las autoridades municipales, formalmente no existen.

La cantidad de DMIs legalmente establecidos, en relación a las 3 ADIs, se debe a que primeramente existe una marcada diferencia demográfica (la densidad de población indígena es mucho mayor en Bolivia que en Chile), y por otro lado, y principalmente, ya que la figura de los Distritos, como parte de la LPP es fomentada a ser implementada en todo el territorio nacional con la sola solicitud de los interesados, mientras que las ADIs se conforman en casos excepcionales y a pedido expreso de la CONADI.

En ambos casos existe la libertad de decisión respecto a la cantidad de población para conformar un ADI/DMI, lo que significa positivo para algunos grupos indígenas que poseen poca población, lo que los hace vulnerables (tal es el caso de Pacahuara, Machineri, Tapiete en Bolivia y Yagán y Kawashkar en Chile).

En el año 2000 el gobierno chileno mediante MIDEPLAN retoma la idea de fortalecer las $\mathrm{ADIs}^{32}$, sin embargo institucionalmente la CONADI y el MIDEPLAN discuten la idea de no implementar otras ADIS, sino más bien focalizar todos los recursos y demás esfuerzos en las ya aprobadas formalmente hasta ahora.

\footnotetext{
${ }^{30}$ En la zona amazónica, por sus características de tipo ecológico, principalmente se da la combinación de distritos municipales étnicos y de preservación (en el Beni 5 distritos mixtos de un total de 8 DMIs)

${ }^{31}$ Fuente:Unidad de Fortalecimiento Comunitario-Viceministerio de Participación Popular. Información al respecto es difícil de encontrar. El Ministerio de Asuntos Indígenas, así como la Unidad de Distritación del Ministerio desconocen tal información. Existe de parte del Estado poco interés por una análisis de la situación de esta temática de forma general, se profundiza mucho en estudios de caso.

32 Esta tendencia se nota en la producción de documentación respecto al tema ADIs, además de la organización de dos seminarios (Concepción 1999 y 2000) denominados "ADIS una tarea necesaria"
} 


\section{iv) Estrategia, planificación y ejecución del desarrollo indígena en los DMIs y ADIs}

La bondad de las leyes dependerá naturalmente de la manera en que son llevadas a la práctica. Para implementar las políticas y los programas que enfocan al desarrollo desde ambas figuras (las ADIs y los DMIs) se generaron y aplicaron (o debieron/deberían aplicarse) diferentes metodologías que a continuación detallamos.

En el caso chileno existe una propuesta metodologíca de planificación de las ADIs realizada en el 2000 , mientras tanto en el caso boliviano la metodología está casi consolidada $^{33}$, esto ya que la figura de los Distritos existía como unidad de planificación desde la Ley Orgánica de Municipalidades de 1985 y por lo tanto había una base metodológica. Actualmente existe en el Viceministerio de Planificación Participativa una Unidad denominada "de Planificación Participativa" que es la encargada de llevar a cabo la labor de proponer metodologías (y ponerlas a prueba) para el desarrollo de los municipios y en algunos casos específicamente de los Distritos Indígenas. La metodología consta de cuatro etapas como a) preparación y organización, b) diagnóstico con perspectiva étnica de la UGTI, c)definición de la estrategia de desarrollo y d) articulación del Plan de Desarrollo Indígena con el Plan de Desarrollo Municipal. ${ }^{34}$

Los gobiernos municipales bolivianos disponen como instrumento político para la elaboración de sus Planes de Desarrollo Municipal y una metodología de planificación participativa. La tarea específicamente para los Planes de Desarrollo Indígena (PDDIs) apoyados por el Manual de Distrit ación Municipal en zonas Indígenas, portador de lo que el estado entiende por "enfoque étnico" ${ }^{35}$. En 1998-1999 esta fue llevada a la práctica en 13 municipios priorizados para obtener la demanda indígena en relación a las necesidades de la población no indígena del municipio.

$\overline{\text { Según los autores de dicho manual, el enfoque étnico de la metodología “... se sustenta en }}$ el conocimiento autoreferencial que tiene las comunidades indígenas de su propia realidad , las potencialidades que permiten organizar los procesos de desarrollo, y las limitaciones y problemas que impiden ese desarrollo..."(MDMzi1997:52). Sin embargo, pareciera ser que al manual de Planificación participativa en zonas urbanas y rurales sirvió de base y sólo le agregaron algunas palabras claves como "gestión indígena" y "producción y economía étnica". En la práctica no hace más que reproducir cualquier metodología de obtención de información con técnicas participativas y autodiagnóstico, priorizando claramente la variable producción. Al no saber abordar a las variables socio-culturales, esta metodología es insuficiente y enfocada desde el punto de vista muy administrativo.

La metodología boliviana tiene varias falencias para su puesta en marcha. Por un lado esta puede o no llevarse a cabo según sea decisión del alcalde y siempre que el presupuesto municipal lo permita. Además, el grupo debe haber sido reconocido formalmente con

\footnotetext{
33 Véase en anexo Cuadros \# 8 y \#9 “Planteamientos metodológicos de intervención” en las ADIs y DMIs respectivamente

${ }^{34}$ Manual de Planificación Participativa en áreas Indígenas VAIPO, PNUD,CIDOB La Paz 1997

${ }^{35}$ Los resultados de dicho manual llevan a conocer información acerca del Diagnóstico de la UGTI, estrategia de desarrollo de la UGTI y DMI y estrategias de ejecución.
} 
anterioridad (al inscribirse como OTB) como "pueblo indígena" y no como "campesinos", como erróneamente muchas comunidades indígenas hicieron. ${ }^{36}$

Estructuralmente el Municipio es el encargado de llevar a cabo (muchas veces mediante Entidades Ejecutoras), los Planes de Desarrollo Municipal y otorgar recursos a los subalcaldes para realizar un Plan de desarrollo independiente. Empero, en la práctica los subalcaldes, al encontrarse en una posición de desventaja, pierden en el juego de poder con los alcaldes, quienes finalmente deciden los programas de inversión.

Otra carencia de la metodología boliviana es que a menudo la participación de las bases es poca e inconstante por la poca credibilidad que tienen en la población indígena este tipo de consultas sobre necesidades básicas en particular y a las promesas municipales y a los agentes del gobierno y ONGs en general.

El proceso planificación y ejecución de los programas o proyectos de desarrollo en ambas figuras involucran a entidades tanto estatales (sectores de educación y salud, representaciones estatales locales como Intendentes regionales, Sub-prefectos departamentales, Alcaldes, Ministerios pertinentes y sus correspondientes unidades, etc., como no gubernamentales (ONGs como entidades de ejecución principalmente).

La planificación en las ADIs, en cambio comienza a ser experimentada, incluso en rigor no existe una metodología aprobada formalmente para el llevar a cabo la acción en las zonas indígenas elegidas por la CONADI. MIDEPLAN por su cuenta se encarga de proponer tímidas metodologías que ponen énfasis en la participación indígena, una gestión a largo plazo y un fortalecimiento del grupo étnico que integra el ADI. Pensando en las ADIs como instrumentos para "enfrentar bolsones de mayor pobreza e indigencia rural y étnica" MIDEPLAN (2000a) propone en síntesis un Plan de desarrollo territorial de las ADIs, que se centra en la infraestructura (mejorar la calidad de vida, elevar las ganancias familiares, y buscar cierta sustentabilidad alimenticia), el derecho a acceder a servicios públicos estatales, el acceso y respeto de recursos naturales, el incentivar nuevas iniciativas económicas. De esta manera se lograrían y que llegue a fomentar y facilitar la sustentabilidad en el tiempo de las ADIs, y se busca generar capacidades en los grupos locales y participación en el desarrollo.

En un documento posterior MIDEPLAN (2000b) plantea una propuesta metodológica que dice sentar las bases que orienten a una política nacional para potenciar las ADIs como espacios territoriales que posibiliten el desarrollo indígena local, sustentable y con identidad. Aunque este documento especifique que la focalización en las ADIs "no debe confundirse con focalizaciones basadas en criterios sociales o económicos, como focalización hacia poblaciones de extrema pobreza..." la metodología parece repetir el esquema anterior, que según las prioridades fijadas por MIDEPLAN "se traduce en una primera etapa en un esfuerzo en infraestructura...se incluyen caminos, electrificación, agua potable, riego, sedes comunitarias y también viviendas.”.(MIDEPLAN 2000b)

\footnotetext{
${ }^{36}$ Orellana (1999) cita el caso de poblaciones de las tierras bajas de Bolivia que no pudieron inscribirse como "comunidad indígena", ya que en el Municipio no se les reconoció su autoidentificación y obligó a utilizar el termino "campesino", y en el altiplano, por que los habitantes indígenas del lugar se identifican como "campesino"por varias décadas después de la Reforma Agraria.
} 
En los documentos de MIDEPLAN, la planificación estratégica para el desarrollo de las ADIs, gira en torno a 5 ejes principales: a) tierra-territorio y aguas indígenas (regularización de la tenencia de estas y mejoramiento productivo), b)promoción de identidad y cultura indígena ( para fortaleces la cultura propia y elevar el nivel de vida), c) fomento productivo y comercialización a modo de subir recursos económicos, d) la protección de riquezas naturales y desarrollo sustentable en base a reconocimiento de conocimientos ancestrales ; y por último c) el mejoramiento de una calidad de vida indígena siendo "los propios indígenas los que determinen el tipo de necesidades y las condiciones adecuadas a sus propias perspectivas etnoculturales." Estas tareas se rían desarrolladas en tres distintos ciclos según corto, mediano y largo plazo en miras primeramente a asegurar la subsistencia, fomentar el mejoramiento de la calidad de vida indígena y por último ejercer un autodesarrollo indígena sustentable. (MIDEPLAN 2000b y CONADI s/f)

Para alcanzar un desarrollo con identidad se plantean "nuevas maneras de hacer gestión", mediante una gestión estratégica, a nivel de dirigentes indígenas y negociaciones al exterior de sus comunidades y por otro lado una gestión operativa; donde la comunidad participa a niveles asociativos, familiares o comunales.

A pesar de las buenas intenciones, si embargo, en el caso chileno se tiende a practicar una priorización estatal de programas de desarrollo muchas veces solamente tomando como base encuestas directas a los beneficiados, aunque se supone que en el futuro se pondría en práctica la metodología citada anteriormente.

El involucramiento de instituciones gubernamentales y no gubernamentales en la puesta en marcha de las figuras de desarrollo indígena, interfieren la rápida acción, implementación de políticas, evaluación de éstas, etc. por la burocracia que este tipo de coaliciones representa, pero por otro lado, se favorece la unión de esfuerzos, recursos, además de experiencias. ${ }^{37}$ Para ahorrar recursos y tiempo, una posibilidad en el caso chileno sería relacionarse los Planes de las ADIs con los PLADECO como sugiere el informe de Mideplan (2000a:49), con el diseño de un "modelo de gestión de Area de Desarrollo Indígena". Sin embargo, por otro lado, la Ley Orgánica Constitucional de Municipalidades (\#. 18.695) determina la confección de los PLADECO como una función privativa de los Municipios.

Un ejemplo de la descoordinación entre instituciones relacionadas con estas figuras y la burocracia que significa su interrelacionamiento se dio en el caso del ADI Lago Budi, cuando el borrador decreto que había sido elaborado por la CONADI con objetivos bastante concretos e integrales para el desarrollo de la zona fue cambiado y simplificado por MIDEPLAN justo antes de su aprobación. Así mismo se sabe que existieron retrasos de parte del MIDEPLAN, encargado de aprobar los decretos de creación de las ADIs propuestas por la CONADI a su debido tiempo. (Aylwin 00)

\footnotetext{
37 Podemos citar el caso de el ADI "Atacama la grande", cuya delimitación concuerda con las fronteras municipales de San Pedro de Atacama y se obtuvo una duplicación de información en los informes Planes de Desarrollo Comunitario (PLADECO) que quinquenalmente realiza el Municipio. Debido a que se utilizan diferentes metodologías de recolección de datos y análisis de estos, basados en los diferentes objetivos de cada proyecto, los resultados suelen ser diferentes, aunque las necesidades son las mismas.
} 
Los Planes de desarrollo deberían ser en ambos casos la base de la puesta en marcha de la política indígena focalizada, siendo que la información es vigente y ha sido obtenida expresamente para tal fin. Muchas veces por falta de recursos no se realizan estos planes, o de otra manera se realizan con carencias de enfoque étnico, por lo que los programas resultados de estos no cubren necesidades de los beneficiarios.

Pensamos que como "enfoque étnico", deberían tomarse aspectos de cosmovisión, de planificación tradicional, y otras variables que a largo plazo influencian en la puesta en marcha de los planes y no solamente referirse a la organización o aspectos productivos. Como ejemplo se puede decir que las experiencias de las tierras bajas de Bolivia (y otras zonas indígenas en general) interpretan el futuro de otra manera, es decir, su cosmovisión de futuro no es como la occidental, por lo que cuando se habla de proyectos "a largo plazo", puede no concordar con la concepción indígena de futuro, de "mejor futuro".

En la práctica el uso de este supuesto "enfoque étnico", podría decirse que no es más que la misma metodología con algunos toques de carácter étnico. También podría relacionarse con lo que Díaz Polanco (1989:36) califica como "ventriloquía étnicista" que utiliza el Estado para hablar en nombre de los indígenas "hacer hablar a los indígenas" o "secuestrarles la palabra" por la imposibilidad de negarles el derecho al habla. Sin embargo, aunque se trate de un discurso más, y la actitud del Estado sea criticada por utilizar medios para llegar a otros fines o como crear una imagen de protección a las poblaciones indígenas $\mathrm{y}$ en realidad no serlo, creemos importante comenzar por este reconocimiento formal.

Las políticas que practican tanto Bolivia como Chile están dentro de las corrientes o variantes indigenistas como "indigenismo étnicista o etnodesarrollista", que para el citado autor no son más que construcciones para justificar ciertas políticas.

Más que utilizar estas técnicas a modo de justificar políticas, creemos que la metodologías con un incipiente "enfoque étnico" se deben a una falta de coherencia entre lo que se puede obtener y lo que se necesita de información. A medida que se vayan poniendo en práctica esperamos que se puedan pulir para así obtener mejores resultados

\section{iv) La territorialidad}

Los conceptos "distrito" y "area", concebidos como unidades de gestión del desarrollo indígena en las legislaciones en estudio, nos hablan de la importancia que reviste la territorialidad y el manejo de los recursos naturales para el mundo indígena, íntimamente relacionado con su cultura. Ambos aspectos, cosmovisión de tierra-territorio y el uso de recursos naturales, son de suma importancia en el desarrollo de los pueblos indígenas y deberán tenerse en cuenta a la hora de elaborar políticas en su favor.

Ahora bien, cada gobierno ha entendido de diferente manera el territorio como base del desarrollo indígena. Desde ya afirmamos que en ningún caso las figuras de las ADIs y los DMIs significan en la práctica una suerte de formalización de poderío respecto de territorio, si no que se trata de delimitaciones geográficas en miras a planificar y ejecutar planes y programas de desarrollo. 
En cuanto al caso chileno, es destacable que las ADIs no se restrinjan a una delimitación geográfica exclusiva de las propiedades legalmente reconocidas como tierras indígenas, pues dichas áreas corresponden a zonas de una "alta densidad" de población indígena, pudiendo afectar indistintamente distintos tipos de propiedad (indígenas y no indígenas, fiscales y particulares, urbanas o rurales), como sucedió en el caso de San Pedro de Atacama o Puerto Saavedra. Por otra parte, las ADIs no se oponen ni coinciden necesariamente con la división administrativa del Estado (Región, Provincia, y Comuna) porque constituyen unidades nuevas de planificación o gestión que no consideran la división territorial para fines administrativos. Por ejemplo, la ADI Lago Budi comparte las Comunas de Puerto Saavedra y T. Schmidt.

La delimitación territorial de las ADIs no respeta ni se basa necesariamente en las fronteras étnicas de la población indígena involucrada. Los límites son determinados por el MIDEPLAN. En los hechos, en las tres ADIs aprobadas hasta la fecha (Bio Bio, Atacama y Lago Budi) existe una diferencia entre las fronteras oficiales y las etnohistóricas de la población involucrada, en los tres casos de mayor extensión.

En consecuencia, una crítica a las ADIs es la manera arbitraria en que se efectúa la delimitación territorial pues podrían cometerse acciones discriminatorias hacia poblaciones que se encuentran fueras de las fronteras oficiales generando un desarrollo desigual. Es el caso de comunidades de la II Región que reclamaron haber sido excluidas de la ADI "Atacama la Grande", o de comunidades pehuenches que quedaron fuera de la ADI Alto Bio Bio, o algunas comunidades mapuches que no fueron incorporadas en la ADI Lago Budi. En el primer caso planteado, que afecta a la comunidad atacameña, para saldar estas contradicciones, la agrupación involucrada planteó la creación de una ADI denominada "Atacama la Chica", que incorpore los grupos atacameños urbanos residentes en Calama y otras comunidades excluidas.

La circunstancia que las ADIs no correspondan al "territorio indígena" tiene un efecto desestructurador a nivel de grupo macro. Sugerimos que en lo sucesivo más que establecerse límites fijos al momento de delimitar futuras ADIs, deberían tomarse en cuenta áreas de influencia amplias y flexibles.

La situación de los DMIs de Bolivia es distinta en la medida que aunque no pretende interrumpir la división administrativa del Estado, respeta mejor las fronteras etnohistóricas. Hay que destacar que en buena parte de los casos los DMIs han sido propuestos por las bases transformándose en unidades de gestión que tienen como base la organización indígena tradicional.

En el caso boliviano, los DMIs son territorios ocupados por agrupaciones indígenas macro, es decir, "unidades armónicas indígenas conformadas por varias comunidades con organización tradicional vigente que las agrupe", distribuidos en varias unidades de la división política estatal. La figura de la Mancomunidad pretende priorizar la territorialidad étnica sobre las fronteras administrativas. Según la ley, la Mancomunidad tendrá por objetivo "preservar su unidad socio-cultural" (art.27-IV). 
Por ejemplo, el pueblo Weehnayek se distribuye en los Municipios de Yacuiba y Villa Montes, del Departamento de Tarija, y se ha constituido en una Mancunidad de Distritos Indígenas.

En todo caso, si bien el hecho que un ADI pueda traspasar varias comunas o que se constituyan una Mancomunidad de DMIs, soluciona en primera instancia la desarticulación comunitaria indígena producida por la arbitrariedad en la creación de fronteras indígenas a nivel central, la experiencia demuestra que la burocracia dificulta la gestión en la medida que ahora es necesario interrelacionarse con varios municipios con un mismo propósito (Orellana 99, Lema 2000. El grupo étnico dependerá de diferentes municipios, planes de desarrollo y procesos de planificación, y deberá lidiar con diferentes gobiernos municipales. Si ya es difícil la dependencia con autoridades de mentalidad cerrada frente al desarrollo indígena, incluso contrarios en muchos casos a la creación de DMIs o a la participación indígena, más complicado será negociar con varias de estas instituciones para arribar a acuerdos a favor de la población indígena.

La diferencia a favor de los DMIs es que la institucionalidad boliviana respeta fronteras étnicas pues pueden constituirse a solicitud de los interesados, mientras que las ADIs chilenas son delimitadas por el mismo Estado chileno. Este distinto tratamiento legal puede sólo en parte explicarse porque la población indígena ha perdido muchas veces la adscripción a grupos territoriales macro por el fraccionamiento del territorio original o por la desestructuración de la organización tradicional, lo que es menos evidente en el caso boliviano.

Las opiniones de entendidos (Orellana 99, Bravo s/f, Duran, Mideplan 2000b) coinciden en señalar que ambas figuras podrían ser en sus respectivos países un buen comienzo para una reestructuración de la cartografía geo-política nacional y dar paso a un ajuste de ordenamiento territorial. Los DMIs serían la base para crear una nueva división políticoadministrativa eficiente acorde con la nueva gestión municipal y con la organización social. Se trata de un proceso a largo plazo que podría comenzar con la creación de Distritos municipales en general, mediante resoluciones municipales. A pesar que las ADIs son más un instrumento de gestión estatal que de planificación territorial, como es el caso de los DMIs, podrían éstos estar a la base de una futura "definición de una política territorial indígena".

Un paso adelante lleva el gobierno boliviano que ha implementado la figura de las Unidades de Gestión Territorial Indígena (UGTIs) delimitando zonas de acción. Las UGTIs son "unidades básicas de organización indígena intercomunal o supracomunal" y se constituyen en el nivel organizativo que debe ser reconocido por el Municipio en el proceso de distritación y es base para la elaboración de Planes de Desarrollo Indígena que deben ser articulados a los Planes Operativos Anuales del Municipio. Estas Unidades pueden transformarse algún momento en DMI, pero no son legalmente lo mismo. Ambas figuras abren el camino para la institución de la otra.

A pesar de que la Ley del Instituto Nacional de Reforma Agraria, aprueba la figura de las Tierras Comunitarias de Origen mediante las cuales "se garantizan los derechos de los pueblos y comunidades indígenas y originarias sobre sus tierras comunitarias de origen tomando en cuenta sus implicaciones económicas, sociales y culturales y el uso y 
aprovechamiento sostenible de los recursos naturales renovables de conformidad con lo previsto en el Artículo 171 de la Constitución Política del Estado...” (Ley INRA, Art. 3 II), jurídicamente no se establece ninguna relación de gestión o administración entre ambas figuras, siendo éstas también unidades de gestión legalmente establecidas con títulos de propiedad de territorios indígenas.

Otra desventaja de las ADIs es que la LI no reconoce el derecho a las organizaciones indígenas de federarse, lo que potenciaría "su capacidad de interlocución y negociación con las entidades públicas existentes en ella" (Aylwin 00), sobre todo entre las comunidades que se encuentran dentro de esta unidad territorial o dentro de territorios etnohistóricos.

Un problema que podría ser hacer calificar a las figuras legales de estudio como "discriminatorias", es el hecho que éstas han sido pensadas para población rural que habita territorios históricos y tradicionales, dejando de lado a la población indígena urbana. Estos constituyen, en el caso de Chile, la mayoría y tanto en Chile como en Bolivia son consideradas como poblaciones urbanas marginales. ${ }^{38}$

En relación al derecho a los recursos naturales existentes en territorios indígenas, la LI en su artículo referido a las ADIs especifica poco, más bien profundiza este tema en otros artículos, aunque en un principio se pensaron estas Areas en función a la preservación del medio ambiente y de los recursos naturales locales. En Bolivia leyes como la Ley forestal, la INRA, etc. son las que se encargan de otorgar derechos y deberes sobre recursos naturales y medio ambiente a la población indígena.

En conclusión, es necesario ampliar derechos y especificaciones sobre recursos naturales y proteger el medio ambiente dentro de un marco normativo. Como ejemplo se pueden citar el caso de varias poblaciones de la Amazonía boliviana, donde a pesar de estar el territorio legalmente titulado y constituido como Distritos Indígenas, la presencia de terceros en éstos y la creciente explotación ilegal de recursos naturales, hacen que estos derechos otorgados por ley sean frágiles y obstruyan el desarrollo al que se quiere llegar. En este mismo sentido, a pesar de los derechos concedidos por la LI y la inversión social que traerá aparejada, el desarrollo en la ADI "Atacama la Grande" corre el riesgo de ser inexistente al no garantizarse agua ni tierra productiva, a sabiendas que la agricultura es una de las principales actividades de subsistencia para y depende del recurso de agua vital.

\section{vi) Gestión Indígena}

A nuestro parecer un DMI funcionará regularmente y cumplirá sus objetivos cuando:

1)-El subalcalde indígena sea sido elegido por la comunidad y sea legitimizado en su gestión por los que lo llevaron al cargo;

\footnotetext{
${ }^{38}$ El gobierno de Chile si tiene mediante la CONADI una oficina regional en Santiago que se encarga exclusivamente de la problemática de los habitantes indígenas en zonas urbanas y diseña políticas de desarrollo enfocadas a esta población.
} 
2)-Las autoridades del Municipio del cuál depende el subalcalde acepten la autoridad indígena, la respetan, y la hagan participar en las decisiones municipales (acerca de proyectos, inversiones, etc.);

3)-El PDDI sea elaborado en su totalidad y refleje las necesidades del pueblo indígena del DMI ;

4)-El territorio que conforma el DMI tenga un desarrollo económico y social;

5)-La organización del grupo sea fortalecida en base a su situación territorial;

6)- Se facilita a nivel administrativo la prestación de servicios públicos;

Por su parte, un ADI funciona regularmente y cumplirá los objetivos de la ley cuando:

1)-Las instituciones pertinentes funcionen coordinadamente para implementar programas de desarrollo;

2)-Se incrementen niveles de vida de las poblaciones indígenas involucradas;

3)-Se proteja a la población indígena y a su medio ambiente y recursos existentes en el área;

Mientras que en la LPP boliviana se confiere la autoridad de los DMIs en los subalcaldes, quienes podrán ser "autoridades originarias de la unidad socio-cultural reconocidas según usos y costumbres", para el funcionamiento de un ADI no se prevee ningún órgano de administración como alcalde o intendente, ni mucho menos se hace un llamado a un indígena para ocupar algún cargo del ADI. Un DMI tendrá como principal autoridad un subalcalde, que será encargado de la gestión y dependerá del alcalde. Este, por su parte, dependerá del Consejo Municipal, por lo que las decisiones del subalcalde son más que nada representativas de la Unidad de gestión.

Ahora bien, el funcionamiento del ADI dependerá de un consejo donde intervendrán principalmente las autoridades de los gobiernos regionales (Intendente) y los Municipios secundados por las autoridades que sean delegadas por las comunidades indígenas involucradas en el Area.

Puede afirmarse que la ley boliviana abre un espacio mayor a la participación indígena en el cargo de subalcalde de los DMIs. Con todo, ésta en la realidad lo que hace es mencionar esta posibilidad indicando en su art. 26 que "se tomarán en cuenta a las autoridades originarias de la unidad socio-cultural". La idea remite a una posibilidad y no a un derecho u obligación de que los Subalcaldes sean indígenas.

En la práctica se da el caso de subalcaldes nombrados directamente por los alcaldes, autoridades que no cuentan con el consentimiento de los indígenas involucrados, lo que ha generado una desacreditación del DMI como institución y provocado diferencias al interior 
de las organizaciones indígenas. ${ }^{39}$ En otros casos la "participación" se reduce a meras respuestas de cuestionarios y encuestas o la presencia física, sin derecho a sugerencias de los subalcaldes en reuniones municipales.

Aunque la LI no dispone explícitamente el derecho de participación indígena en la gestión de las ADIs, los organismos involucrados en la creación de éstos mencionan la importancia de la participación indígena en su desarrollo.

De manera general creemos que los indígenas chilenos se encuentran en ventaja en relación a los indígenas bolivianos, en el aspecto de la calidad de gestión, en términos de conocimientos prácticos y relacionados al desarrollo en diferentes áreas. En efecto, mediante la LI, aparte de priorizar la educación en idioma nativo, se otorgan becas a estudiantes indígenas con presupuesto del sector público para todo nivel de educación, desde básica hasta pos grado.(Art. $33 \mathrm{LI})^{40}$ Este fomento a la educación va en crecimiento lo que significa que ha tenido gran aceptación en las bases y se espera que los resultados sean medibles a corto plazo.

Es de esperarse que las becas indígenas en distintas especialidades faciliten la constitución de grupos de indígenas capacitados para enfrentar tareas como la participación, la planificación del desarrollo y gestión de las ADIs desde un enfoque propio. Se sabe por ejemplo que en el caso mapuche, el proceso de profesionalización indígena, aporta y fomenta la élite intelectual y/o política del movimiento mapuche (Foerster 99).

Sin embargo, creemos que la participación y consecuente "gestión indígena" junto con la capacidad de desenvolverse en ámbitos públicos y políticos debe ir más allá de una capacitación. Al hecho de ser indígena y tener además capacidad profesional debe acoplarse el tener compromiso con sus hermanos de sangre y ser consecuente con las labores a ejercer desde estos puestos "claves".

Los Comités para la gestión de las ADIs, gestionados desde MIDEPLAN con apoyo de las comunidades beneficiarias y donde participa además la CONADI, no son suficientes si no aprovechan los liderazgos locales, ni se generan capacidades en los grupos locales. (MIDEPLAN 99) Un modo de fortalecer las capacidades sería por ejemplo tomando en cuenta indígenas para la elaboración de los planes de factibilidad y preinversión que se realizan en todas las ADIs y que mediante licitaciones son entregadas a ONGs.

Una crítica general a las normativas relativas a la participación indígena en la ADIs, es que éstas deben ser específicas, aclarando actividades y niveles de participación indígena y no sólo ser figura para concentración de recursos administrativos. En los DMIs la misma figura del subalcalde no está bien definida, y en las ADIs no se especifica el rol ni el grado de participación de los interesados.

\footnotetext{
39 Tal es el caso del pueblo indígena Weehnayek citado por Lema

40 El objetivo de la otorgación de becas indígenas es el de "formar recursos humanos calificados que promuevan la valoración y desarrollo de las lenguas y culturas de los pueblos indígenas en todas las instancias de la vida nacional." (CONADI 1999). A nivel Nacional se otorgaron importante número de becas como sigue: 1994 (5.000), 1995 (5.390), 1996 (5.600), 1997 (6.000), 1998 ( 11.000$), 1999$ ( 11.414)
} 
En los DMIs preocupa la capacidad de gestión de los subalcaldes, además del tipo de relación de estos con los alcaldes. Muchas veces los funcionarios del Municipio dependiente no ceden funciones a los subalcaldes por que no creen en su capacidad, o por que la misma ley no les delega ninguna responsabilidad explícita.

La Ley Orgánica de Municipalidades boliviana debió haber especificado más las características y el rol de los subalcaldes y determinar su relación con los Alcaldes municipales. Sin embargo no lo hizo y el espacio se queda vacío, provocando malas interpretaciones o carencias de actividades en la figura de los subalcaldes indígenas.

La creación de muchos DMIs han sido apoyadas por ONGs o por instancias gubernamentales $^{41}$, pero estas no han hecho un seguimiento o fortalecido a las autoridades y comunarios en general en el manejo del DMI en la etapa posterior. Se habla entonces de DMIs como "ficticios", por que solamente existen en papel (como resolución municipal) (Kudelka 1999). Sus autoridades no son reconocidas por el Municipio, ni por las bases. Son ficticios además, por que los habitantes de los DMIS desconocen su existencia y por lo tanto sus derechos en éste. Los primeros DMIs se crearon con apoyo de la SAE y SNPP “... en un proceso arbitrario, tomando como punto de partida las necesidades especialmente de los pueblos indígenas, no la administración municipal." (Balslev 1997:18)

\section{$\underline{\text { La buena gestión: Algunos ejemplos concretos }}$}

Especialmente en el caso boliviano pueden citarse ejemplos de buena gestión, por que la experiencia del funcionamiento de estas instituciones permite hacerlo, en relación a las 3 ADIs que existen formalmente.

Los pocos Distritos Indígenas que funcionan regularmente deben su éxito por un lado a la experiencia y la capacidad de sus dirigentes adquirida antes de la promulgación de la LPP y por lo tanto antes de constituirse en DMI. (Mullucundo 97, Lema 2000) Ese podría ser el caso de los pueblos Guaraníes y Guarayos de Santa Cruz, quienes han basado el funcionamiento de su subalcaldía gracias a su coordinado trabajo con su organización tradicional.

El caso del chaco, la Capitanía guaraní de Kaipependi Karahuaicho, mantiene buena relación con ONGs y por su credibilidad y organización ha sabido captar recursos externos al municipio. En el caso de muchos DMIs del pueblo guaraní, su alta capacidad de gestión hace que tengan mucha autonomía de decisión en cuanto a proyectos de inversión en relación a otros pueblos como los Yuracares que están bajo la tutela de agentes externos a su pueblo, como es el caso de ONGs .

Otro caso ejemplar en la gestión indígena es el caso del pueblo Rapa Nui de la Isla de Pascua en Chile, donde la LI rige con ciertas excepciones para este pueblo y si bien aún no ha sido declarada legalmente Area de Desarrollo Indígena, aunque existe ya la solicitud de la CONADI para su conformación, el modelo de cogestión es excepcional. Mediante la cogestión de indígenas Rapa Nui y autoridades estatales chilenas, se creó la Comisión de

\footnotetext{
${ }^{41}$ Unos ejemplos son DMI Urubichá cuya creación fue apoyada por la prefectura y la SNPP, en el chaco Kaiapependi Karahuaicho por SNPP y SNAEGG y en el norte de Potosí la SAE (1996), entre otros.
} 
Desarrollo de Isla de Pascua (CDPI), que tiene por objetivo incidir en decisiones referidas a la tenencia de territorio, ampliación de tierras y planificación y gestión del territorio pascuense. (Andueza 00). Se trata de un modelo "de administración intercultural", que ha sido posible gracias a una larga negociación entre los indígenas y el Estado, cuyo anteproyecto de ley (de 1993) fue rechazado en un principio por que necesitaba un estatuto jurídico especial.(CONADI s/f).

La figura del ADI descrita en la Ley no menciona expresamente la existencia de cierta "autoridad" que lidere el ADI, dejando abierta la posibilidad a la gente de base para buscar representaciones. A manera de ejemplo, los indígenas de las comunidades que conforman el ADI Lago Budi reunidos en diciembre del 2000, reconociéndose desinformados de lo que es o debería pasar en el ADI o de no ser tomados en cuenta para fines de planificación y decisión del ADI (a 3 años de su conformación legal) decidieron organizarse para relacionarse con el Estado con el fin de fortalecer esta entidad y aprovechar los beneficios que les otorga por ley. Desde que se llevó a cabo este Trawün o encuentro mapuche, el ADI cuenta con un representante de todas las comunidades involucradas. En esta importante reunión, traducida luego en un documento de difusión para instancias que promuevan su desarrollo, los indígenas sentaron las bases de lo que entienden por desarrollo y el modo que pretenden relacionarse con el Estado respecto al ADI. ( Com. Juan Trawun 2000)

\section{$\underline{\text { La mala gestión }}$}

Los DMIs que no funcionan regularmente se quedaron en la etapa de haber sido constitución y de asignación de un subalcalde, sin avanzar en la gestión misma del Distrito. Podemos nombrar tres principales razones para este resultado. Por un lado, hizo falta apoyo institucional (ONGs, Gobierno, etc.) para la consolidación del mismo y falta de apoyo a nivel del Municipio, existiendo una negativa de parte de alcaldes a reconocer a los Subalcaldes formalmente y proveer de recursos y apoyo necesario para su funcionamiento. Finalmente por el desconocimiento de las funciones de los DMIs, que fueron vagamente difundidos aún en la etapa de la creación de DMIs y poco claro en la Ley.

Al implementar la LPP se da un tipo de relaciones desiguales desde el punto de vista del poder (Oxhorn s/f, Mullucundo 97). Los subalcaldes son manipulados social y políticamente por los alcaldes al depender directamente de ellos. Se practica además una especie de corporatismo, que puede desencadenar en un autoritarismo de parte de los gobiernos municipales de turno, además de corrupción y mal uso de recursos, tanto de poder, como de gastos. Además existen duplicidad de autoridad entre el subalcalde y el corregidor, en el caso que el DMI se extiende más de una sección de provincia., creándose dualidad de poderes de las organizaciones ya existentes (principalmente sectoriales) y las llamadas por la Ley Organizaciones territoriales de base (OTBS).

El apoyo institucional es pobre, pues pocas ONGs apoyan a los DMIs en cuestiones de demandas territoriales, derechos indígenas, formulación de perfiles de proyecto, fortalecimiento a la organización, etc. (principalmente en la zona andina).

Otra de las limitaciones en la gestión de los DMIs es el desconocimiento de canales y fuentes de financiamiento para posibles proyectos o demandas principales de las comunidades. Hace falta capacidad de gestión, pero también voluntad para utilizar los 
mecanismos dispuestos por Ley como el de Comité de vigilancia, planificación participativa, etc.

A veces la elección de los subalcaldes no coincide con la organización tradicional, debido a que los pobladores se asientan dispersamente en el caso amazónico y chaqueño principalmente, y tradicionalmente no existe una sola jefatura, sino jefaturas familiares dispersas. En el caso del DMI Yuqui-Yuracaré, se han conformado dos diferentes UGTIs siendo que ambos comparten un solo territorio.

En base a la experiencia analizada, se concluye (Balslev 97-Semo 99) que cada Distrito Indígena parte de sus características étnicas para poner en práctica en la gestión de los DMIs en asuntos de organización y de gestión administrativa y se distinguen por capacidad de organización y gestión y consecuentes relaciones con el gobierno Municipal correspondiente.

\section{vii) La Participación indígena}

El derecho a la participación de las poblaciones indígenas en políticas y decisiones relacionadas con su desarrollo es internacionalmente reconocido por las NNUU. En el Convenio 169 de la O.I.T., su artículo 2 señala que: “...los gobiernos deberán asumir la responsabilidad de desarrollar con la participación de los pueblos interesados, una acción coordinada y sistemática con miras a protegerlos derechos de esos pueblos y garantizar el respeto a su integridad”. Así mismo, el artículo 7 indica que “..los pueblos interesados deberán tener el derecho de decidir sus propias prioridades en lo que atañe al desarrollo, en la medida que este afecte en sus vidas, creencias, instituciones, bienestar espiritual y a las tierras que ocupan...y de controlar...su propio desarrollo económico, social y cultural."

Más allá que la participación se considere un derecho y una reivindicación, creemos que ella tiene varios aspectos. Por un lado, el derecho a la participación debe tener como contrapartida el deseo y la capacidad de las poblaciones en orden de hacer efectivo este derecho. Puede que el derecho a la participación exista, pero que los que deben ejercer la participación no estén dispuestos a hacerlo, por falta de interés o por falta de capacidad. La práctica del "derecho a participar" está acompañada de cierto grado de compromiso étnico, capacidad técnica y lo que se llama capital cultural.

La ley boliviana, basada en el convenio de la OIT, es más explícita que la chilena en esta materia. Esta última no hace mención a la participación indígena en la planificación y ejecución de proyectos de desarrollo en las ADIs. La LPP en cambio formula mecanismos para llevar a cabo una participación ciudadana, participación de la sociedad civil en general, dentro de la cual incluimos la indígena. Los DMIs contemplan la participación indígena en todas las instancias legales, siendo la principal el derecho a participar políticamente dentro del Municipio respetándoseles sus características étnicas.

La LI determina el grado de participación de las comunidades indígenas de la siguiente manera: "los servicios de la administración del Estado y las organizaciones de carácter territorial, cuando traten materias que tengan injerencias o relación con cuestiones 
indígenas, deberán escuchar y considerar la opinión de las organizaciones indígenas que reconoce esta ley."(Art.34)

Específicamente la Ley reconoce la necesidad de la participación indígena en las Areas de Desarrollo que estén ubicadas en las Areas silvestres protegidas y "considerará" la participación de las comunidades ahí existentes sobre los derechos de uso de recursos naturales principalmente. ${ }^{42}$ El regular funcionamiento de las pocas ADIs constituidas y la falta de participación en las ADIs, podría deberse a la falta de liderazgos locales y a la pobre difusión acerca de derechos en el ADI. Es importante también aclarar en este sentido, que a diferencia de la participación indígena boliviana dentro de los DMIs, los líderes indígenas no deberán necesariamente relacionarse con partidos políticos para ejercer como representantes.

El objetivo de las ADIs con todo, es la focalización de acción e inversión social estatal "en beneficio del desarrollo armónico" de los indígenas, no especificando el papel de los indígenas en este proceso (salvo en áreas silvestres protegidas). Es necesario aclarar que en la práctica, los documentos oficiales del MIDEPLAN y de la CONADI (especialmente de los últimos dos años) reiteran la importancia de la participación indígena y además la fomentan en congresos, a talleres, etc. "Se busca el desarrollo con identidad sobre la base de la participación indígena como del respeto de los derechos humanos...”, “...es absolutamente necesario, que dentro de la planificación y ordenamiento territorial se incorpore la participación y la creatividad a nivel local, tanto por la variable ambiental, como por las tendencias demográficas y sociales se determinan cambios en las estructuras..." (CONADI s/f)

Por último, y para dejar en claro la opción del gobierno en un marco general de participación indígena el discurso del Presidente Lagos de mayo del 2001 aclara: "quiero señalarles que la participación será el eje de la política y programas indígenas. Para ello crearemos mesas regionales de trabajo que permitan la participación de todos en torno a sus problemas específicos."

Según la idea de la CONADI, en las unidades de desarrollo indígena, las poblaciones beneficiarias tendrían derecho a participación y/o oposición a dichos programas. Estas llamadas en un principio "unidades básicas de gestión” “...tendrán derechos especiales como el derecho de las comunidades a participar en la toma de decisiones y por tanto a oponerse a ellos(...), el derecho a beneficiarse de la explotación de los recursos naturales, y el derecho a que se privilegie la capacitación, contratación y empleo de la mano de obra indígena en las faenas o industrias acordadas." (CONADI s/f pp9).

En esa idea, se vincula, entonces, la participación indígena, como elemento integrante de desarrollo indígena. El cuerpo de la LI y de la figura de las ADIs al no establecer la participación directa de los indígenas en la formulación de planes de desarrollo, entrega la labor planificadora exclusivamente a la CONADI, junto con MIDEPLAN. En la práctica

\footnotetext{
${ }^{42}$ El grado de participación indígena será determinado por la Corporación Nacional Forestal, CONADI y Servicio Agrícola y Ganadero de común acuerdo. (Art. 35 )
} 
contarán con un tipo de participación indirecta (respondiendo encuestas, por ejemplo), sin que tengan derecho a objetar las políticas en su favor.

Ahora bien, como el actual funcionamiento de las ADIs no abre formalmente espacio para la participación ${ }^{43}$, las comunidades indígenas debieran "apropiarse de la planificación y gestión dentro de las ADIs" - o a lo menos "consensuar programas de desarrollo que sean ofertados por la CONADI”.(Rev CONADI)

Mediante la Ley (relacionada además para fines de gestión con otras como la LOCGAR o LCOM), el funcionamiento de las ADIs deberá estar a cargo del Intendente regional (representando el gobierno regional) y encargados de las oficinas regionales de la CONADI, los que de manera coordinada deberán buscar relacionarse para fines de planificación, ejecución e inversión de proyectos con diversas instituciones.

En base a la experiencia de las ya creadas ADIs, en 1998, en una evaluación se decidió institucionalmente iniciar la búsqueda "de un marco de referencia para un desarrollo autosustentable con identidad cultural, donde los principales aspectos sociales, culturales, políticos del mundo indígena se combinen con las necesidades de la sociedad chilena en su conjunto..." (MIDEPLAN 99).

Parece ser que la reflexión (MIDEPLAN 00a) hace llegar a la necesidad de un desarrollo relacionado a la capacidad de autogestión y a la identidad cultural. No es suficiente la constitución jurídica de las ADIs. Se necesitan "respuestas con identidad" que saldrán de una participación activa y no sólo "programas estándar".

\section{viii) Los recursos}

Para la inversión social que precisan estas figuras y así llevar a cabo su objetivo de promover el desarrollo socio-económico de las poblaciones indígenas, es importante analizar las fuentes de financiamiento que precisan y el manejo de recursos.

En el caso chileno de las ADIs, el financiamiento de los programas de desarrollo serán básicamente coordinado por la CONADI y se basarán en recursos estatales provenientes primeramente de esta entidad, pero esta a su vez podrá firmar convenios con otras públicas y privadas con el mismo fin. Las instituciones que se vean involucradas con el desembolso de recursos económicos (y planificación de programas) en el caso de las ADIs chilenas en diferentes campos son, por ejemplo, Municipios, SERNATUR, etc.

Pueden darse tres tipos de inversión en las ADIs: la inversión pública directa, la inversión pública sectorial y regional, y, por último, la inversión de tipo privado, nacional o internacional.

Para acceder a los recursos para financiar las obras, fuera de los ingresos del Municipio de la coparticipación tributaria, depende de cada DMI buscar otros ingresos de inversión. Las entidades estatales de desarrollo (FNDR, FIS, FDC) ofertan recursos a los DMIs, pero tras

\footnotetext{
${ }^{43}$ Se hace una excepción en el caso de Rapa Nui, donde los indígenas pascuences si tienen el derecho de participación y opinión acerca de los planes de desarrollo en su territorio.
} 
una larga tramitación burocrática. Para la solicitud de algún tipo de financiamiento, el DMI debe aportar desde un $5 \%$ a un 30 de co-financiamiento.

Los recursos de los municipios en la mayor parte de los casos no son suficientes para atender las demandas priorizadas por los DMIs. Así muchos programas no se llevan a cabo por pocos recursos del municipio y por otro lado por falta de capacidad de gestión de la subalcaldía para buscar co-financiamiento.

En la zona andina, pocos son los DMIs que buscan apoyo financiero como entidad se dio excepcionalmente el caso del DMI Qaqachaca, quienes como entidad organizada solicitaron apoyo financiero a entidades Japonesas, mientras que lo mismo hicieron miembros del DMI Qhayana con apoyo de la FAO.

Un punto muy importante que no está establecido de manera explícita en las Leyes es el hecho de que los recursos de financiamiento deben buscarse de manera permanente y aparte de las inversiones es necesario tomar en cuenta la importancia de buscar formas de sustentabilidad y sostenibilidad de los programas a largo plazo.

\section{ix) Autonomía y autogestión}

Cuando hablamos de "Areas Indígenas" o "Distritos Indígenas", podríamos imaginarnos cierta relación a un grado de independencia de gestión y de una especie de gobiernos indígenas. Sin embargo, la autonomía se hace humo al hacer depender ambas políticamente de otras instancias burocráticas (municipios o CONADI e intendentes regionales) así como financieramente, al recibir directamente recursos económicos para invertir en lo que los indígenas vean prioritario hacerlo.

En la práctica, mediante los DMIs es más complicado construir una unidad de gestión con cierta autonomía al depender el subalcalde de las decisiones alcalde, por un lado, y al no obtener los recursos de la coparticipación tributaria directamente. Al no existir cierta autonomía no existe autogestión y por lo tanto no se puede hablar de un desarrollo con identidad. (Orellana 99)

A la "participación política", es decir en la toma de decisiones y opinión en la planificación de programas a favor de los pueblos, debe sumarse un tipo de "autonomía económica", decisión sobre las inversiones en la zona en coordinación con las instituciones que focalizan su acción en pro del desarrollo.

Si tomamos en cuenta la definición de Durston (1995) de autonomía y autodeterminación como "focalización y división de funciones entre el gobierno central, regional y local, como complementaria y sinérgica" y no como "la existencia de un Estado dentro de otro Estado", los DMIs se encuentran dentro de este tipo de instituciones que promueven la autonomía indígena. No se trata, sin embargo, de una autonomía de tipo financiera (los recursos a invertir no llegan directamente a los indígenas) ni de tipo política, los indígenas y sus autoridades siguen dependiendo de otras instancias superiores.

La LI, por su cuenta, niega la posibilidad de autonomía ni contempla llegar a ésta en un futuro mediato ni inmediato. Según Naguil (1997), al no poder dar paso a la 
autodeterminación juntamente con derecho primordiales y relacionados con esta como el derecho a la autoafirmación, a la autodefinición, a la autodelimitación y a la autodisposición interna y externa, el Estado chileno niega la "liberación del pueblo mapuche."

En síntesis, aunque pueden hablarse de diferentes tipos de autonomías según sus objetivos y alcances, creemos que difícilmente los Estados abrirán posibilidades jurídicas para el tipo de autonomía (más de tipo política) que reclaman los indígenas, ya que ni siquiera Convenios internacionales avalan un grado tan alto de independencia interna dentro de los Estados-naciones.

El tipo de autonomía del que Durston habla es más bien un tipo de descentralización administativa y financiera que se puede encontrar en otros casos también en América (Colombia, Nicaragua en la Costa Atlántica, e incluso en los llamados "Selfgobernments" o "Autogobiernos" de indígenas canadienses. 


\section{Capítulo 4)}

\section{CONCLUSIONES}

- Aunque tanto los gobiernos chileno como boliviano reconocen la existencia de población indígena y además pretenden "preservarla" y "difundirla", los derechos y atribuciones que se le otorga están circunscritos en la lógica globalizadora del Estado. El hecho que se les reconozca territorio y autoridades indígenas no significa de manera alguna el otorgamiento de cierto grado de autonomía integral, que contenga aspectos financieros como políticos, que sea determinante para la preservación armónica del grupo étnico y un desarrollo según propias necesidades y convicciones.

- Si los derechos materiales exigidos por los indígenas en sus demandas han sido cuidadosamente resguardados a través de los DMIs y las ADIs, los derechos de tipo jurídico quedan relegados a un plano teórico o para solucionarse a largo plazo. Los derechos de tipo simbólico van con el tiempo teniendo cada vez más respaldo del parte del Estado al insistirse en el respeto a las culturas y validez de sus diferencias con la cultura nacional.

- Aunque las intenciones legislativas es favorecer un desarrollo sustentable social y políticamente, las metodologías de intervención no han sido bien pensadas y, por tanto, el desarrollo al que aspiran no será diferenciado. Los beneficiarios de estas políticas no están conscientes de la necesidad de asumir un "enfoque étnico" en relación a las políticas públicas. Por otro lado, entre ambos sectores (estatal e indígena) hay una deficiente comunicación. Creemos necesario que los funcionarios públicos que trabajan en esta temática/problemática deben estar comprometidos con su labor en beneficio del sector indígena.

- Ciertamente los resultados de la puesta en marcha de las leyes juntamente con las figuras legales de las ADIs y los DMIs son limitados. Pero hay algo que debemos rescatar, y es el hecho meritorio que los países se reconozcan multiétnicos (Bolivia en su constitución y Chile en su ley) y que siguiendo corrientes internacionales, comiencen a hablar de "desarrollo indígena" "áreas indígenas", "políticas étnicas", "enfoque étnico" y "municipios indígenas". Aunque estos términos están siendo utilizados por el momento sin darles realmente una fuerte carga étnica, pueden constituirse en una base para políticas futuras diferenciadas del resto de políticas sociales.

- Es importante hacer notar la poca claridad que tienen los Estados en cuanto al tratamiento del tema de la pobreza indígena. En la práctica han venido mezclando (por confusión teórica, por falta de carencia en las políticas o a modo de "despistar" a indígenas y estudiosos del tema) el tema pobreza indígena con la otorgación de derechos indígenas. Si bien, es un deber enfocar y actuar directamente para contrarrestar la pobreza, los Estados no han obtenido buenos resultados con simples políticas para erradicarla, posiblemente debido a razones de tipo simbólico-cultural

- Los indígenas se encuentran en ambos casos dentro de la "sociedad civil débil" lo que viene reforzado por un principio de relacionamiento con el Estado enmarcado dentro de 
parámetros burocráticos. La solución a la falta de "capital cultural" y capacidad de gestión (principalmente en el área rural y áreas marginales de las ciudades), requisitos ambos para una participación activa, debe ser abordada con políticas a largo plazo, que tomen en cuenta cambios constantes de dirigentes, especializando a indígenas de diferentes sexos y edades según áreas de trabajo y gestión, planificación, ejecución, inversión, etc.). Al ponerse en práctica la educación intercultural bilingüe, deberían tomarse en cuenta estos conocimientos y formarse dirigentes indígenas especializados en la gestión y desarrollo. Les toca a las comunidades apropiarse y adecuar a su manera la planificación y gestión dentro de las ADIs y de los DMIs ya que estos se constituyen una oportunidad para el pueblo indígena para construir propuestas propias bajo algunos requisitos y condiciones como el fortalecimiento de la sociedad civil (especialmente la rural) y fortalecimiento de la economía y formación de recursos humanos indígenas.

- También hay que mencionar que las relaciones de ambos Estados con las poblaciones indígenas se hallan de cierta manera desgastadas, y los indígenas son muchas veces incrédulos ante nuevas políticas, lo que significa además una barrera en el proceso de desarrollo. También hay que reconocer que existe heterogeneidad, primeramente en cuanto a las características de cada grupo indígena para enfrentar su desarrollo y en cuanto al tipo de relacionamiento de cada pueblo indígena con el Estado y a partir de esto las reivindicaciones con sus consecuentes resultados pasa a ser también diferentes.

- Pareciera ser que los indígenas de ambos países tienen dos alternativas en cuanto a las políticas que profesan sus gobiernos. La primera es entrar en las estructuras de poder (difícilmente "respetando las suyas propias") y aprender caminos que lleguen a un desarrollo estructurado desde el Estado teniendo diferencias conceptuales con el sector indígena; o bien marginarse de este tipo de políticas y seguir siendo partícipes de las cifras de pobreza en censos y encuestas.

- En base a lo descrito anteriormente, y como conclusión final, creemos que no se puede hablar de un "desarrollo indígena", si es que no se deja de lado el concepto occidental de "desarrollo" tendiéndose más bien a enfocar de manera integral la situación del sector indígena y tomando como base las demandas referidas a derechos simbólicos, políticos y materiales, que en conjunto signifiquen definitivamente una mejora en la calidad de vida de los indígenas. Esta "calidad de vida" debe ser afrontada desde su propio enfoque, sin que por ejemplo las necesidades básicas sean tomadas meramente como "recursos materiales".

Como fruto de este "desarrollo", es necesario llegar a una mejora en las relaciones del sector indígena y las instituciones estatales que trabajan con ellos. Para complementar estos requisitos y alcanzar un "desarrollo indígena" es necesario reforzar la identidad indígena, como pretende hacer la Ley Indígena y las políticas practicadas por la CONADI chilena, pero junto con ello aumentar las capacidades de gestión y los mecanismos de participación. 


\section{BIBLIOGRAFIA}

-ANDUEZA, Pablo

2000

- "Hacia el reconocimiento de los derechos de los pueblos originarios: el modelo de cogestión en la Isla de Pascua". Ponencia presentada en el Congreso de derecho consuetudinario, Arica

1997

-La nueva Ley Indígena Chilena, Historia, contexto internacional y análisis

normativo En: Revista de ciencias sociales \# 42 Publicación de la facultad de derecho y ciencias sociales, Universidad de Valparaiso, Chile

-AYLWIN, José

2000

Materializaciones y conflictos Aplicación de la Ley indígena en el territorio mapuche (1994-1997) Instituto de estudios Indígenas, Temuco 2000

- BALSLEV, Anne

1997

Distritos Municipales Indígenas en Bolivia, las primeras experiencias Subsecretaría de Asuntos Etnicos, MDH, La Paz

- BRAVO, Eduardo

1999

Areas de Desarrollo Indígena, CONADI

Temuco, Mimeo

-BONFIL B. , Guillermo

1995

OBRAS ESCOGIDAS Tomo II

Ed. INI, CIESAS México

\section{-COMUNIDADES DEL ADI LAGO BUDI}

Gran asamblea "Kiñe Futra Trawün Tain Lof Meu"

Documento de la reunión efectuada en Puaucho el 15 y 16 de diciembre del año 2000

-CONADI

$\mathbf{s} / \mathbf{f} \mathbf{a}$

- "Areas de desarrollo indígena: análisis jurídico y concordancias”

Temuco, Mimeo

\section{0}

- Construyendo de la mano con la diversidad, Memoria Oficina Asuntos Indígenas de Santiago, Santiago

\section{0}

- Seis años al servicio de las personas, familias y comunidades Mapuche Huilliche 19941999, Dirección Regional CONADI, Osorno

- Areas de Desarrollo Indígena, Unidad de Planificación Dirección Nacional $\quad s / f b$ 
TEMA: Areas de Desarrollo Indígena

Año ${ }^{44}$ II Nr. 7, Octubre

\section{-DURSTON, John}

"El etno desarrollo de cara al siglo XX"

Cuaderno de la CEPAL LC/R 1578

1997

-.Sustentabilidad cultural y desarrollo indígena CEPAL, Santiago

-FOERSTER, Rolf

1999

"Movimiento étnico o movimiento etnonacional mapuche?"

En: Revista Critica Cultural \#18 Santiago, Junio

-Frigolett , D., Diaz, et al

1999

Seminario : Areas de Desarrollo Indígena: una tarea necesaria ( Concepción,12 y 13 de agosto 1999) Documento de trabajo, Mimeo

-GRAY, A

1996

Los pueblos indígenas en Naciones Unidas

En: Revista Mundo Indígena 1995-1996 IGWA Copenhague

- Gobierno de Bolivia, Ley INRA (1996)

- Gobierno de Bolivia, Ley de Participación Popular (\# 1551) (1994)

- Gobierno de Bolivia, Ley Orgánica de Municipalidades (1999)

- Gobierno de Chile, Ley Indígena ( \#19.253) ( 1993)

-KUDELKA, Ana

1999

Metodología de planificación participativa en zonas indígenas: el caso de los Uru Iru Itu Tesis, Ms. La Paz

-LEMA, Ana María

"Indígenas y/o alcaldes en Urubichá, Gutierrez y Villa Montes"

En: Revista Tinkasos, PIEB, Nr.6, Mayo La Paz

-LAGOS, Ricardo

Discurso presidencial del 21 de mayo de 2001-06-27

-LIBERMANN, K.(Coord.)

1992

Ed. Nueva sociedad, ILDIS, La Paz

44 
-MARIMAN, Pablo

1997

"Demanda por tierra desde el programa del movimiento mapuche (1930-1970)"

En: Revista LIWEN \# 4, Centro de Estudios y documentación mapuche LIWEN, Temuco

-MIDEPLAN

- Balance del trabajo realizado por MIDEPLAN en torno a las ADIs, 26 agosto 1999

- Informe Final, Grupo De Trabajo Para Los Pueblos Indígenas, Stgo mayo 2000 a

- Bases par una política de desarrollo y potenciación de las ADIs en Chile, Julio 2000 b

- Segundo seminario nacional Areas de Desarrollo Indígena: Experiencias y perspectivas para el desarrollo indígena (Documento borrador) Concepción, Agosto $\quad \mathbf{2 0 0 0}$ c

- MULLUCUNDO, Eugenio 1998

Participación Indígena en los Municipios y los distritos Indígenas

Tesis para optar al grado de Maestría en Ciencias políticas

( Ms.), La Paz

-NAGUIL, Victor

1997

"Desarrollo mapuche y derecho de autodeterminación"

En: Revista Liwen \# 4 Centro de Estudios y documentación mapuche LIWEN, Temuco

-ROMERO,

1999

En: Orellana, et al, Municipios y Pueblos indígenas: Problema del modelo municipal y propuesta social de creación de Municipios especiales (Ms.) CEJIS, Santa Cruz

-Organización Internacional del Trabajo (OIT) 1989

Convenio "sobre pueblos indígenas y tribales en países independientes"

(Convenio \#169)

-ORELLANA, René 1999

Autogestión sin autonomía? Municipio Indígena y pluralización del Estado

En: Orellana, et al, Municipios y Pueblos indígenas: Problema del modelo municipal y propuesta social de creación de Municipios especiales (Ms.) CEJIS, Santa Cruz

-OXHORN, Philip (s/f)

La construcción boliviana del Estado por la sociedad civil: La Ley boliviana de Participación popular y el desafío de la democracia local

(Tesis, Mc Gill University), (Ms)

-PLANT, Roger

1998

Pobreza y desarrollo indígena, algunas reflexiones

Doc. BID, Washington

(En: WWW.Fondoindigena.com)

-PSACHAROPOULOS, G y PATRINOS, $\mathrm{H}$.

1994

Indigenous People and poverty in Latin America

En: Rev. Finance \& Development Marzo 
- SALAZAR, Gabriel, Comp. 1998 Autonomía , espacio y gestión, El Municipio cercenado Ed. LOM, Santiago

- SEMO, Placido y Laura, Mateo 1999

"Análisis de los servicios de apoyo a la inversión en la gestión de distritos municipales indígenas" Ministerio de Desarrollo Sostenible y Planificación, Mimeo, La Paz, Abril

- STAVENHAGEN, Rodolfo 1989

Comunidades étnicas en Estados modernos

En: América Indígena III 1 Vol. XLIX, México

-VADILLO, Alcides

1997

"Constitución Política del estado y Pueblos Indígenas"

En: El pulso de la democracia: Participación ciudadana y descentralización en Bolivia Ministerio de Desarrollo Humano, Nueva Sociedad, La Paz

-Viceministerio de Participación Popular y Fortalecimiento Municipal

1999

(Unidad Nacional de Planificación Participativa)

Sistematización de las experiencias de Planificación Participativa en Areas Indígenas para la formulación de Planes de desarrollo Distritales Indígenas en Bolivia, La Paz, Mayo

- WILLAING, Birgit

"Five years of popular participation"

Tesis (Ms. s/f)

\section{Otras fuentes:}

\section{-Entrevistas:}

\section{En Chile}

-Rolf Foerster, Profesor de la Universidad de Chile, (9 /12/ 99)

-John Durston, Departamento Social, CEPAL, ( 3/12/ 99)

-Andrea Aravena, Directora de la Oficina de Asuntos Indígenas de Santiago (8/01/00)

-Rodrigo Valenzuela, Departamento de evaluación social del MIDEPLAN (22/11/99)

\section{En Bolivia}

- Wigberto Rivero, Ministro de Asuntos Indígenas y Originarios, Bolivia (12/02/ 01)

- Doris Vidal, encargada de política indígena y planificación territorial, Viceministerio de Asuntos Indígenas y Pueblos originarios (VAIPO) (5/02/01) 